\title{
SEGMENTI NARODNE MEDICINE
}

\author{
Petra KELEMEN \\ Filozofski fakultet Sveučilišta u Zagrebu \\ Odsjek za etnologiju i kulturnu antropologiju \\ Ivana Lučića 3, 10000 Zagreb
}

\section{UVOD}

U istraživanju narodne medicine stanovništva Krivoga Puta kroz prve razgovore s kazivačima izdvojile su se pojedine teme koje čine okosnicu ovoga prikaza. ${ }^{1}$ Naime, narodna medicina, kao široko područje istraživanja, sadrži brojne aspekte, čitav niz pitanja, praksi liječenja, tumačenja, a njezina zastupljenost i značaj razlikuju se ovisno o zajednici koja je prakticira, odnosno prepoznaje kao važan segment svoje svakodnevice. Upravo njezin različit status može otvoriti neka pitanja i pokušati pružiti odgovore o opravdanosti njezina uključivanja u istraživanje, odnosno naznačiti smjernice za daljnja proučavanja koja će se temeljiti na prikupljenoj građi. Podaci koji se donose u ovom radu pružaju upravo takav temelj. Obrađene segmente narodne medicine sami su kazivači prepoznavali kao one koji čine dio prakse liječenja vremenski omeđene uglavnom sredinom 20. stoljeća. ${ }^{2}$ Nestrukturiranim intervjuom ${ }^{3}$ dobiveni su, tako, podaci koji najbolje govore o statusu narodne medicine, o tome koliko je sjećanje na neke njezine elemente, koji u suvremenosti nisu prisutni, ustvari živo te kolika je svijest o ovim oblicima liječenja uopće prisutna kod Krivopućana. Različita kazivanja, ponekad i oprečna, govore tako više o različitim pogledima nego o različitoj zastupljenosti, te onemogućuju davanje zaokružene slike sastavnica narodne medicine na ovom prostoru. Ipak, kao vrijedna građa mogu poslužiti daljnjim provjerama i istraživanjima ove seoske zajednice.

Prikupljeni podaci u ovom se radu donose u cjelinama koje su se same nametnule tijekom boravka na terenu te su tako predstavljale topose oko kojih su se vodili razgovori. ${ }^{4}$ Prva cjelina obuhvaća ljekovite trave te proizvode poput meda i različitih masti. U drugoj se iznose podaci o liječenju vezani uz pojedine bolesti, poput upale uha, oka i povišene tjelesne temperature, postupci kod prijeloma kostiju te priče vezane uz suseljane koji su obavljali ulogu zubara. Nadalje, tema poroda zasebna je cjelina u kojoj se iznose podaci vezani uz porode kod kuće. Posljednji dio donosi podatke o higijeni na području Krivoga Puta. Zaključni dio rada čine kazivanja iz kojih se mogu iščitati pojedina razmišljanja o položaju narodne medicine, nadriliječnicima ${ }^{5}$ koji su provodili pojedine metode liječenja te o prisutnosti elemenata narodne medicine na području Krivoga Puta u suvremenosti.

1 Pri terenskom istraživanju podaci su prikupljeni u sljedećim lokalitetima: Gorica, Francikovac, Katići, Krivi Put, Kuljići, Lucići, Mrzli Dol, Pavelići, Pavići, Popići, Rupa, Rusova Draga, Serdari, Škopci, Šojatski Dolac, Šolići, Špalji, Veljun, Žuljevići.

2 Pojedine je elemente moguće pratiti i u razdoblju druge polovice 20. stoljeća. U radu su naglašene vremenske odrednice.

3 Kao pomoć u pripremi za istraživanje poslužili su podaci prikupljeni Upitnicama Etnološkog atlasa Jugoslavije, tema broj 87. Umivanje, kupanje, pranje iz III. sveska te tema broj 124. Porod, dojenje, prvi zub iz IV. sveska (signatura Krivog Puta - Fd 241, zapisivač Slobodan Šimić, kazivač Milan Krmpotić). Potrebno je naglasiti da su ovi podaci dobiveni od samo jednoga kazivača te kako ni na jednom mjestu nije navedeno na koje se krivoputske zaseoke kazivanja odnose. Usto, budući da su odgovori vrlo šturi i generalizirani te se, primjerice, nigdje ne navode odstupanja od uobičajenog ili različite varijante, oni su u tekstu navedeni samo u slučajevima da se razlikuju od podataka prikupljenih terenskim istraživanjem. Za ostale teme istraživanja izložene u ovome tekstu, upitnicu sam sastavila sama, a prilikom višekratnih terenskih istraživanja prilagođavala sam je prema dotada prikupljenim podacima.

4 O postupcima liječenja zmijskog ujeda govori se u radu P. Kelemen (2004): "Liječenje zmijskog ujeda - priča kao dio sjećanja zajednice”, Senjski zbornik 31, str. 213-238; te u istoimenom poglavlju u ovoj monografiji.

5 Ovaj termin upotrijebio je Milan Prpić Terezin iz Krivoga Puta u odgovoru na pitanje jesu li ljudi prije, kad još nije bilo liječnika, poznavali neke prakse liječenja kod kuće. 


\section{LJEKOVITO BILJE TE BILJNE I ŽIVOTINJSKE MASTI}

\section{1. LJEKOVITO BILJE}

$\mathrm{O}$ d svih sredstava koje je narodna medicina širom svijeta koristila u prošlosti, a koje koristi i danas, ljekovite biljke na prvom su mjestu. (Brenko et al. 2001:81) Terenskim istraživanjem zabilježen je uistinu velik broj ljekovitog bilja koje se upotrebljavalo na ispitanom području. ${ }^{6}$ Pritom su neke biljke, primjerice majčina dušica i bukvica, zastupljene u velikom broju kazivanja, dok je pojedine spomenuo samo manji broj kazivača.

Prilikom istraživanja kazivači su najčešće sami nabrajali biljke i njihova ljekovita svojstva. Na nekim se mjestima kazivanja razlikuju budući da su se pojedinci prisjetili jednog svojstva određene biljke, a drugi opet nekog drugog. Zbog toga je moguće zapaziti raznolikost primjene nekih biljaka i veća ili manja razmimoilaženja u ovdje navedenim odgovorima kazivača. ${ }^{7}$

Za biljku poznatu pod nazivom aptovinalabdovina (divlja bazga, lat. Sambucus ebulus L. porodica Caprifoliaceae) Nada Prpić Terezina i Milan Prpić Terezin iz Krivoga Puta potvrdili su kako se polagala po svinjama za skidanje temperature. Milan Krmpotić Zekonja iz Veljuna i Ive Krmpotić Pićica iz Kuljića objasnili su kako se ona koristila za plućni vrbanac, bolest svinja, a djelovala je tako da je, kad se položila po svinji, izvlačila temperaturu. Ive je pojasnio: Jer ako peče $e^{8}$ izadi van, spašen je, ako peče unutra, ugine. One peče su bile okrugle, izbaci van, ta aptovina izvuci - dobro je. Ako odu unutra, nema da preživi. Istodobno, Zvonko Pavelić Dujela iz Serdara naveo je kako se abdovina koristila kod reume: Za reumu. Onda su ljudi mećali to, vreća, samo velika vreća to bila, to smo mi zvali slamarica, e, nutra se mećala slama i na toj slami se spavalo, a to je bila slama zobena, koja je bila mekana. I onda stari ljudi su mećali tu bujad, paprat $i$ onda su mećali to i na tom su spavali i reuma prode. (...) Onda su isto mećali, kuhali, u vodu i na ruke il dio tijela koji ga boli i odozga pokri $i$ to se parilo. I onda su ti bolovi prestajali i za duže vremena to nije bolilo. Također, Milka Prpić Markina iz Veljuna kazala je: Prvu su babe na glavu mećale kad bi ih glava zabolela, aptovinu, naberi pa metni pod glavu. Aptovina, ona smrdi jako. ${ }^{9}$

Bazgu (lat. Sambulus migra) je pod različitim nazivima (bazga, zobika, bazgovina) spomenulo više kazivača, a razlikuju se i objašnjenja ljekovitog djelovanja ove biljke (sl. 1, sl. 2). Tako je Draga Tomljanović Rilčeva iz Katića objasnila kako je bazga dobra za bubrege, a Milan Prpić Terezin iz Krivoga Puta kazao je kako se sok ove biljke koristio kod slabokrvnosti. Mara Tomljanović Isanova iz Krivoga Puta iznijela je objašnjenje u kojem je dala i zanimljiv podatak o sprezi narodne i službene medicine: Vako, plod zrele zobice kad se napravi pekmez, da je super za liječenje pluća i dišnih organa. To baš mi je jedna doktorica rekla... dobro, da su oni to prije u bolnicama spremali kad nije bilo lijekova i to. Mile Prpić Popić iz Popića kazao je kako se zobika, bazgovina koristila za želudac. Ivanka Krmpotić Šimunova iz Škobaca rekla je kako je biljka bila dobra za bronhitis, dok je Marica Krmpotić Migečeva iz Veljuna objasnila kako se koristila kod prehlade. Nekoliko kazivača potvrdilo je samo da je ova biljka bila ljekovita ne određujući pobliže njezino djelovanje. ${ }^{10}$ Milan Prpić Markin iz Veljuna jedini je donio objašnjenje ljekovitog učinka bazge kod upale uha: I u uho ako čovjeka boli, kapni mu crnoga u uho. (...) One bobice male istisne u uho, onaj sok. Ana Šojat Colaševa iz Francikovca iznijela je sljedeću zanimljivost o bazgi: Moja mama uvik govorila da je to sveto drvo, bazga. I da sretna kuća di bazga raste kraj kuće. Tako da ona meni to uvik govori, tako da ja to uvik beren za čaj.

6 Određeni postupci s nekim biljkama vezani su uz vrijeme pojedinih blagdana, o čemu piše Aleksandra Vlatković u radu o godišnjim običajima Krivopućana u ovoj monografiji.

7 U tekstu će se u napomenama navoditi kazivači koji su se prisjetili pojedine biljke bez da su detaljnije objasnili njezinu ljekovitost. Svi latinski nazivi navedeni u radu preuzeti su iz Brenko et al., 2001.

$8 \quad$ Kazivač je pečama nazvao prišteve koji se javljaju kod ove bolesti.

$9 \quad$ Isto je potvrdio i Milan Prpić Markin iz Veljuna.

10 To su: Ika Pavelić Tomina, Pavići (zobika); Zvonko Pavelić Dujela, Serdari; Marija Prpić Vinina, Veljun (potvrdila je da se bazga koristi i danas); Luka Krmpotić Brnde, Veljun (kazivač je spomenuo: Bazgovina i to, to neko piće pravi.). 


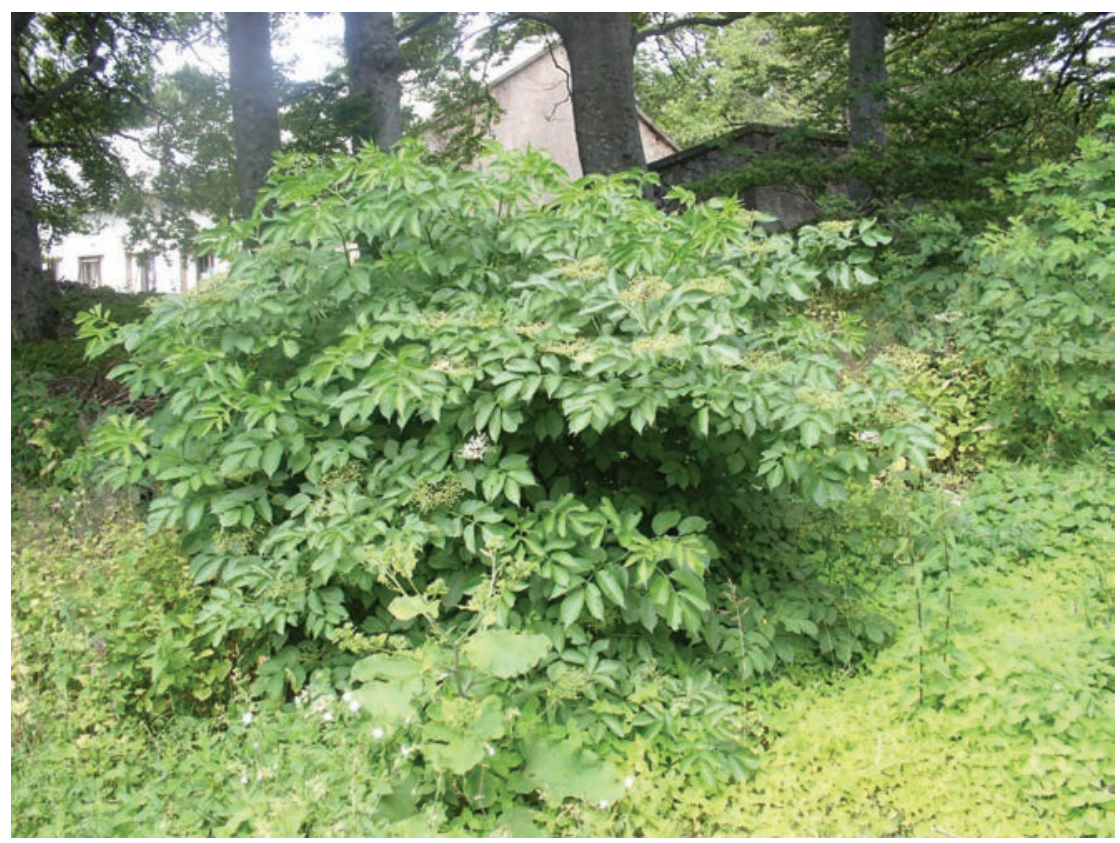

Slika 1: Zobika u blizini kúce Milana Krmpotića Zekonje u Veljunu; snimila Petra Kelemen, srpanj 2005.

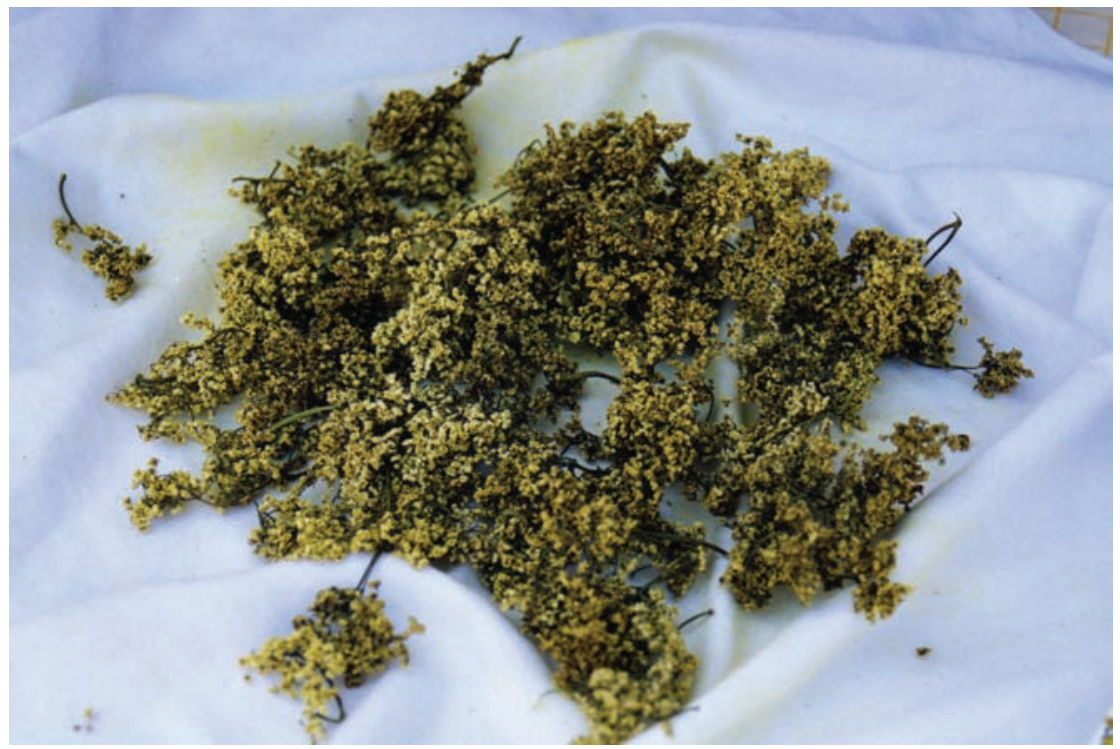

Slika 2: Sušena båga, pripremili Draga i Marko Tomljanović Rilčevi u Katićma; snimio Augustin Perić, srpanj 2005.

Bukvicu (trputac, lat. Betonica officinalis) je spomenuo velik broj kazivača, najčešće navodeći kako se ona koristila kod posjekotina (sl. 3). ${ }^{11}$ Mile Prpić Popić iz Popića objasnio je: I sada taj se list nade $i$ kad bi se čovjek posijeka, to se mete taj list, malo se namaže uljon ili masti rana, taj se list metne i zaveže i za 5, 6 dana zaraste rana. (...) Stoji 5, 6 dana dok ne uvene. I onda kad vi otvorite, već je ova rana malo zacelila i vise

$11 \quad$ Kazivači koji su naveli bukvicu kao biljku koja se koristila kod zadobivenih posjekotina su: Stjepan Prpić Stipina, Gorica; Milan Prpić Terezin, Krivi Put; Josip Blažević Ivela, Mrzli Dol; Milan Pavelić Vranić, Pavićí; Marko Prpić Rus, Rusova Draga; Mile Prpić Popić, Popići; Nevenka Krmpotić Aneličina, Veljun; Josip Blažević Ivela, Mrzli Dol. Mara Tomljanović Isanova iz Krivoga Puta potvrdila je kako se bukvica upotrebljavala za rane, te kako se od nje mogao napravit ko med za dišne organe, al ima muška i ženska. Mirko Prpić Cungo iz Krivoga Puta, Pavla Pavelić Cirilova iz Pavelića, Ana Šojat Colaševa iz Francikovca i Josip Prpić Jurina iz Mrzlog Dola kazali su da se upotrebljavala za rane. 
ne vuče, ono je izvuko oni đubar van nevaljani i koža se zalipi, koža za kožu. Ta bukvica. Nevenka Krmpotić Aneličina iz Veljuna također je naglasila kako se uz bukvicu koristila i domaća mast: A bukvica, kad bi se čovjek posika, onda metni. Namaži je domaćon masti, metni na onu ranu. Josip Blažević Ivela iz Mrzlog Dola također je istaknuo kako se posjekotina namazala svinjskom masti te se tada stavila bukvica. Milan Pavelić Vranić iz Pavića ispričao je: To je bukvica. E, a vidiš, ovaj Bogdan s Ritavca što je bija, on je čuva blago ode u Klanjcu što mi zovemo. I njega uvatija čir, ima je čir na želucu. Izvalija se i leži, ne more nikuda, valja se po livadi. I od muke je zagrabija slučajno ovo i metnija u usta i kad je to zagriza, zgriza je od muke, posle kroz neko vremena puštilo. (...) E, jel puštilo onako od samo svoje il ga baš puštilo na to. (...) E, a kaže da kakve je muke mučija, da je to čudo jedno. (...) Reka je kako je najprije sidija $i$ čuva krave. I posle kad ga je to uvatilo, onda se on izvalija i valja se od muke. I rukon je čupa travu i metnija u usta, nije ni zna što je metnija. Kazivačeva supruga Zdenka Pavelić Vranićeva objasnila je kako je ta trava bila bukvica, no Milan nadodaje: Nije ni zna što je metnije, ali posli je vidija što je otkinija još je ostalo mu u ruki, da je otkinija to i da je proguca i da ga posli puštilo. Onda višse puta upotrebljava to. (...) Za čir. Sad more na primer čir i puknit i pusti sam i bez toga. Al on je bija ubjeden da je trava pomogla. Ana Šojat Colaševa iz Francikovca ispričala je: Meni mama pokojna bila u bolnici, ona je imala ko jedan podljev na peti, to se njoj zgrušala krv unutra, ja san to znala da je to dobro, mazala domaću mast i ja san to njoj privijala. Ova do zemlje. Ima muška i ženska. Ja mislin da su muški okrugli. Kazivačica je pridodala da se bukvica ili, kako je kazala, biljka književno zvana trputac, koristila i za pravljenje sirupa: Od tog se može sirup, za kašalj. Kažu da najbolji. Evo to van je njezina stabljika, od tog trpuca. Jako dobar sirup za kašalj se napravi. Ivanka Krmpotić Šimunova iz Škobaca objasnila je kako su za rane ljudi upotrebljavali i bukvicu, ali su većinom koristili gospinu travu u ulju.

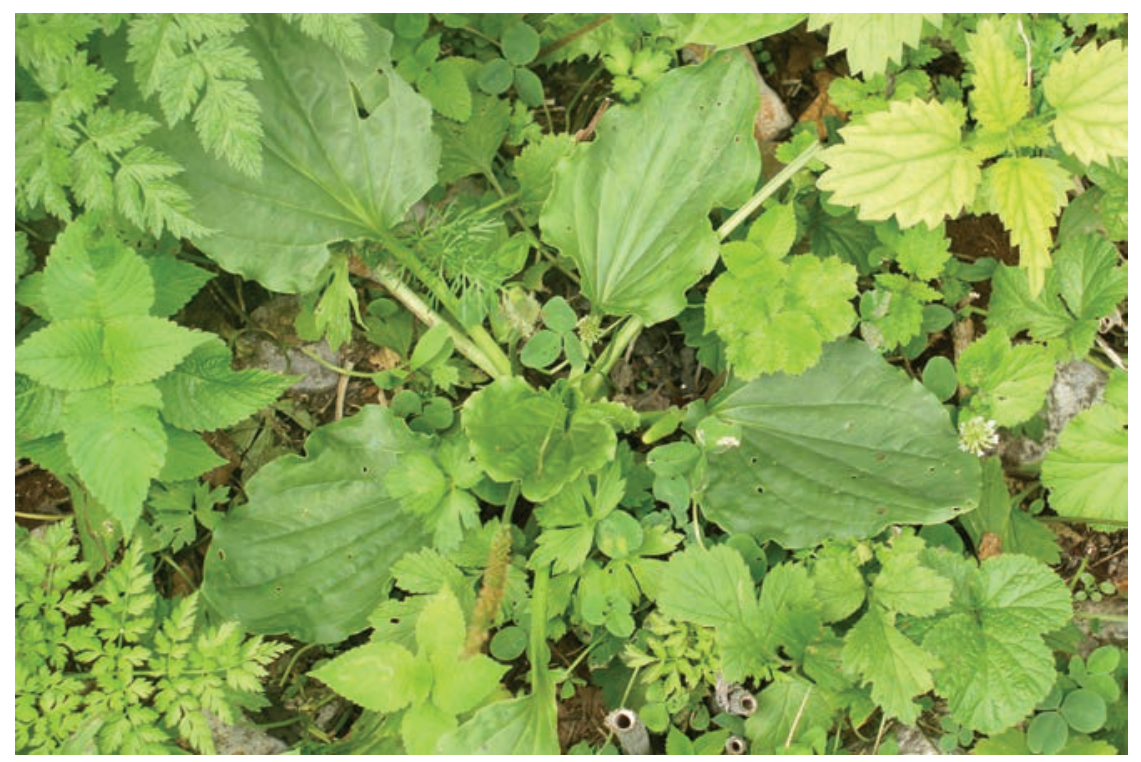

Slika 3: Bukvica kod kuće Mare i Luke Krmpotic Brndinih u Veljunu; snimila Petra Kelemen, srpanj 2005.

O upotrebi gloga (lat. Crataegus oxyantha) ${ }^{12}$ Zvonko Pavelić Dujela iz Serdara kazao je: $A$ da je on za sve bolesti jako dobar, za prehlade, za mokraću, za mjehur. (...) Cvijet, cvijet je jako dobar za prehladu. Onda bobice su se kuhale na razne načine i pripremali ćajeve od toga. I on da je dobar isto za mjehur, za prehladu, to su oni upotrebljavali. Kakve tablete, ko je ima onda tablete. Marica Krmpotić Migečeva iz Veljuna kazala je kako je glog dobar za cirkulaciju krvi te pridodala: Onda u hladu se to suši i to da je za srce dobro taj čaj. Ive Krmpotić Pićica iz Kuljića rekao je kako je glog dobar za srce. Mara Krmpotić Brndina iz Veljuna

12 Glog kao ljekovitu biljku spomenuli su Mira Tomljanović Ropetina iz Krivoga Puta i Josip Blažević Ivela iz Mrzloga Dola (koji je naveo crijet od gloga). 
istaknula je kako je glog dobar za svake unutarnje bolesti.

O upotrebi gospine trave (lat. Hypericum perforatum) (sl. 4, sl. 5) $)^{13}$ Ivanka Krmpotić Šimunova iz Škobaca kazala je kako se na posjekotine stavljalo ulje s gospinom travom: Je, to su stavljali ovo ulje. Toga ja iman $i$ sad, evo, vidite ga tu. A to van se zove gospina trava. To van je ulje za svaku ranu priki lik. Cvijet nadete od gospine trave. Toga sad momentalno nema da van ja mogu to pokazat. I onda ulijete ulje unutra $i$ stavite ovako pokriveno. I sad morate držat na suncu. Dok pocrveni. (...) Da, obično jestivo ulje. A morete $i$ ovo dalmatinsko, maslinovo, a možete i ovo obično ulje. Svejedno. Nema veze to. Ovo je meni obično ulje ovo, jestivo. (...) Dok pocrveni. Dok vako bude crveno, mora stat na suncu. (...) Jedno desetak, 15 dana mora stat ovako pokriveno. I onda to morete mećat na svaku ranu. Stavite ulje i zamotate. Di je zgodno zamotat. A di nije zgodno zamotat, isto se more stavit. ${ }^{14}$ Također, Milan Prpić Markin iz Veljuna rekao je: Za opekline je najbolje gospina trava, ona ima žut cvijet, ona je dobra za svaku ranu. Stavi se ulje, al treba imat pravo maslinovo ulje, ovo su ulja, dica, nikakva, to vi ne znate, prvo toga vraga nije bilo, bilo je maslinovo ulje. (...) I to se stavi u ulje, ta gospina trava, na sunce se metne, pusti takvu lijepu boju. (...) I s tin namaži koja bila rana, ko da je sam Bog liči. Bila opeklina, bilo da si se posika, da se ognojilo nešto. To je jedan priki lik za te stvari. Ana Šojat Colaševa iz Francikovca spomenula je sljedeće ljekovito svojstvo gospine trave: Gospina trava je jako dobra za slabokrvne ljude, ko i ima tegobe sa menzison, a onda za čajeve, za oporavak, za nešto. Zlata Tomljanović Pešina iz Krivoga Puta kazala je kako je gospina trava ili, kako je navela, književno kantarion, bila dobra za bubrege.
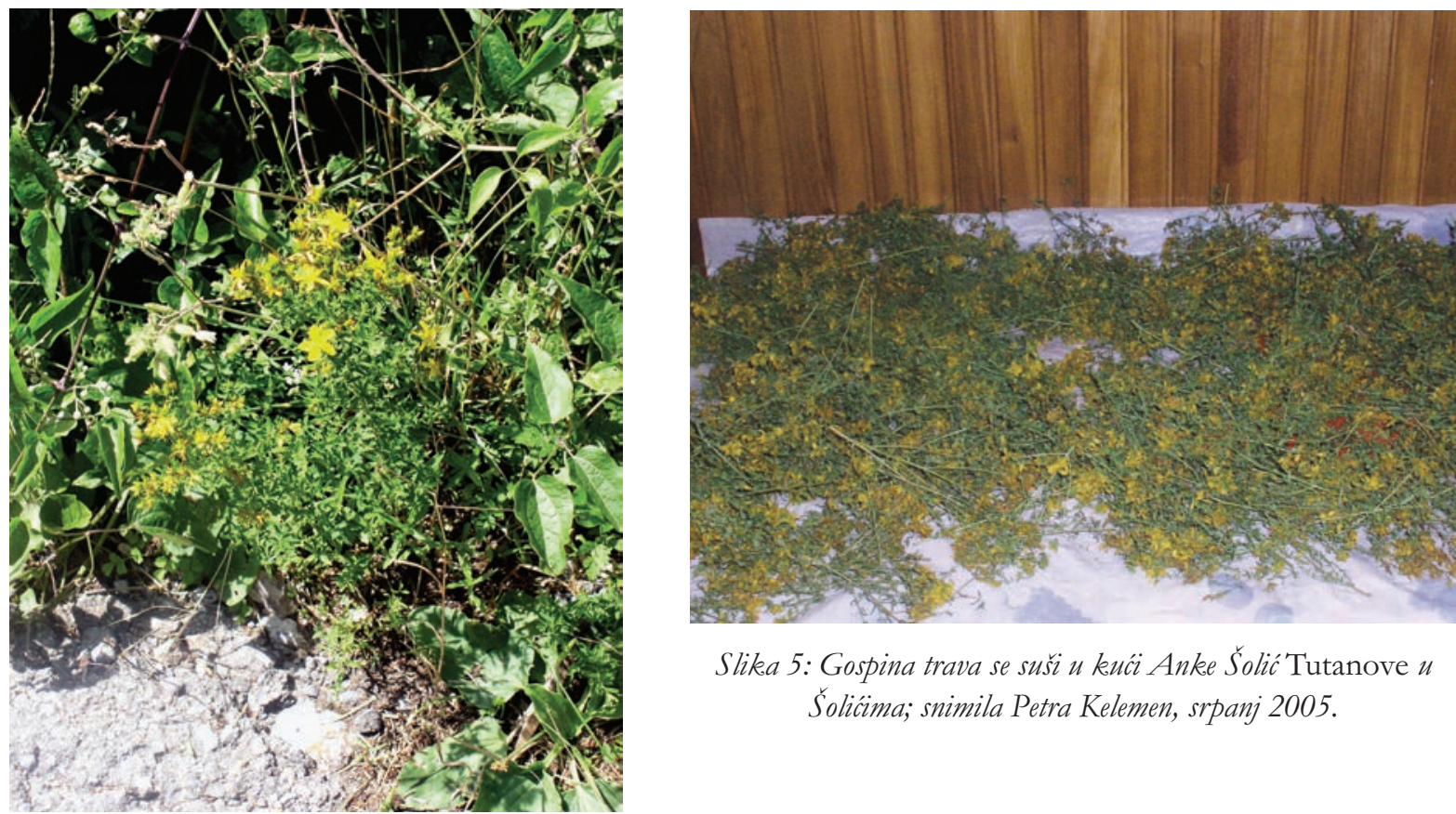

Slike 5: Gospina trava se suši u kucii Anke ŠolićTutanove u Solicima; snimila Petra Kelemen, srpanj 2005.

Slika 4: Gospina trava u blizini kuće Ane Šojat Colaševe

u Francikovcu; snimila Petra Kelemen, srpanj 2005.

Trava iva ${ }^{15}$ se prema riječima Anke Prpić i Ljubice Prpić iz Gorice koristila za ženske bolesti. Kazivačice su navele kako se za nju govorilo: Kažu trava iva - mrtva pravi živa. Milan Pavelić Vranić iz Pavića objasnio je kako se ova trava upotrebljavala za pluća, a o njoj je i pisma kaže - Trava iva izlečila moga sina.

13 Gospinu travu spomenula je Mira Tomljanović Ropetina iz Krivoga Puta, a Zdenka Pavelić Vranićeva iz Pavića navela je kako je njezin čaj dobar za sve. Jadranka Tomljanović iz Veljuna spomenula je čaj od gospine trave.

14 Takvu upotrebu gospine trave spomenula je i Mara Krmpotić Brndina iz Veljuna, no ona sama nije spravljala ulje. Također, Zlata Tomljanović Pešina iz Krivoga Puta kazala je kako se gospina trava u maslinovom ili običnom ulju koristila kao lijek za rane.

15 Biljku je spomenula Ana Šojat Colaševa iz Francikovca. 
Prije su babe starije pivale il koješta. Mile Prpić Popić iz Popića kazao je kako se ona upotrebljavala za prehladu. Marija Prpić Vinina iz Veljuna prisjetila se kako je iva bila dobra za pluća, a spomenula je još jednu izreku povezanu s ovom travom: da je znala majka šta je trava iva, imala bi danas živa sina.

Kadulja (lat. Salvia officinalis) ${ }^{16}$ je prema riječima Pavle Pavelić Cirilove iz Pavelića, Mare i Luke Krmpotić Brndinih iz Veljuna ${ }^{17}$ i Francike Šojat Babićeve iz Šojatskog Dolca bila dobra za pluća, a Mile Prpić Popić iz Popića i Marica Krmpotić Migečeva iz Veljuna kazali su da se koristila za želudac (sl. 6). Nada Prpić Terezina iz Krivoga Puta navela je kako se kadulja koristila i kad bi boljele mandule (krajnici): Jedino kad su bolele mandule, onda kuhala se kadulja pa se ispiralo i tako. Ana Šojat Colaševa iz Francikovca objasnila je: Kadulja za ispiranje usne šupljine za djecu. Jer djeca do 11 godina ne smiju pit od kadulje čaj od cvijeta. Samo od listića. ${ }^{18}$ Prema riječima kazivačice, ova je biljka dobra za pluća, za bronhitis.

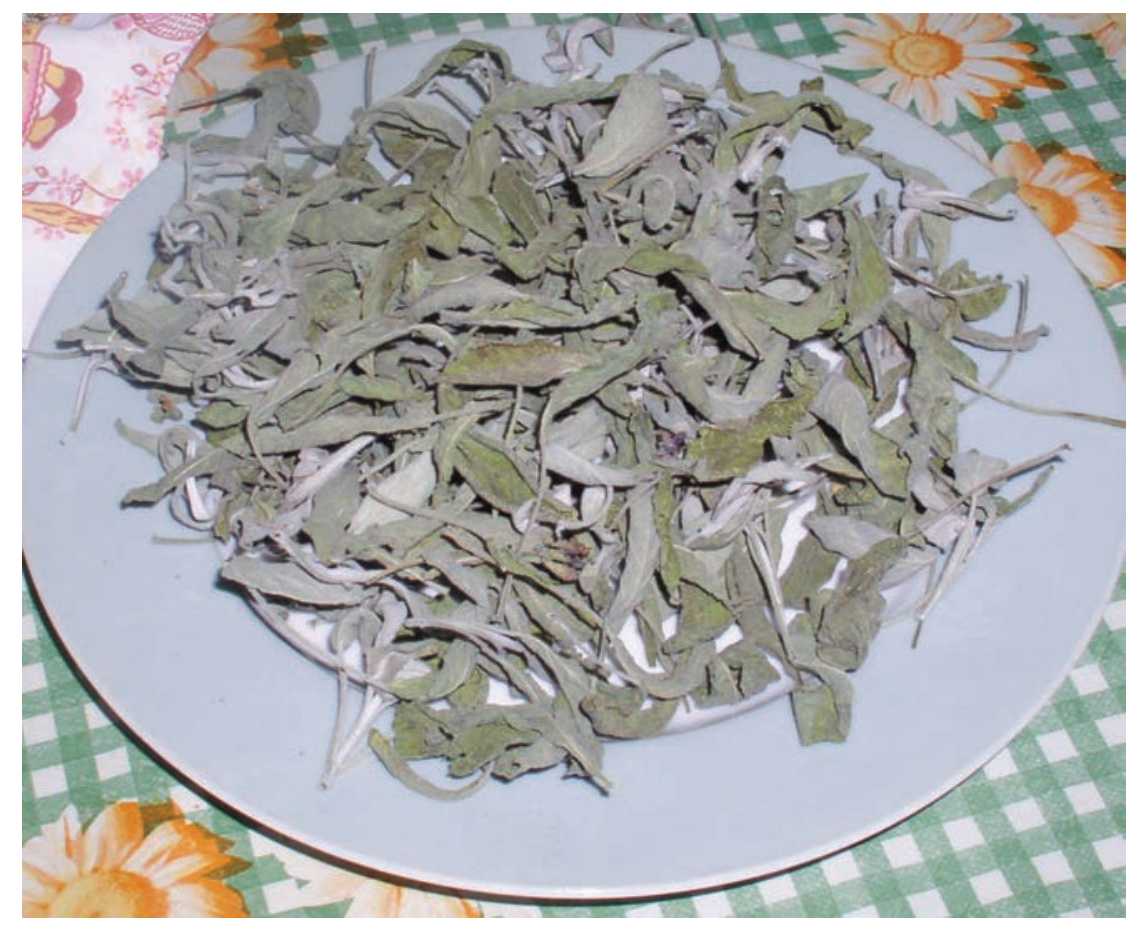

Slika 6: Sušena kadulja, pripremila Ana Šojat Colaševa u Francikovcu; snimila Petra Kelemen, srpanj 2005.

Kamilica (lat. Matricaria chamomilla) (sl. 7) ${ }^{19}$ se, kako je naveo Milan Krmpotić Zekonja iz Veljuna, koristila kod bolova želuca. Mara Krmpotić Brndina iz Veljuna kazala je kako su žene pile njezin čaj kod menstrualnih bolova, a Anka Šolić Tutanova iz Šolića navela je kako je to jako dobro za prat, dole (misli na ženske spolne organe op. a.), ako te peče. ${ }^{20}$

${ }_{16}$ Ovu su biljku spomenuli: Mara Tomljanović Isanova iz Krivoga Puta, Nada Prpić Terezina iz Krivoga Puta i Ivan Pavelić Jandra iz Serdara.

17 Mara Krmpotić Brndina iz Veljuna je napomenula: Ode nema, ima dole. Doli u planini.

18 Kazivačica nije znala pobliže objasniti takvu upotrebu kadulje.

19 Ovu su biljku spomenule Milka Prpić Jurina iz Mrzloga Dola i Francika Šojat Babićeva iz Šojatskoga Dolca koja je naziva kamamilica.

$20 \mathrm{O}$ upotrebi kamilice govori se i u dijelu teksta o liječenju upale očiju. 


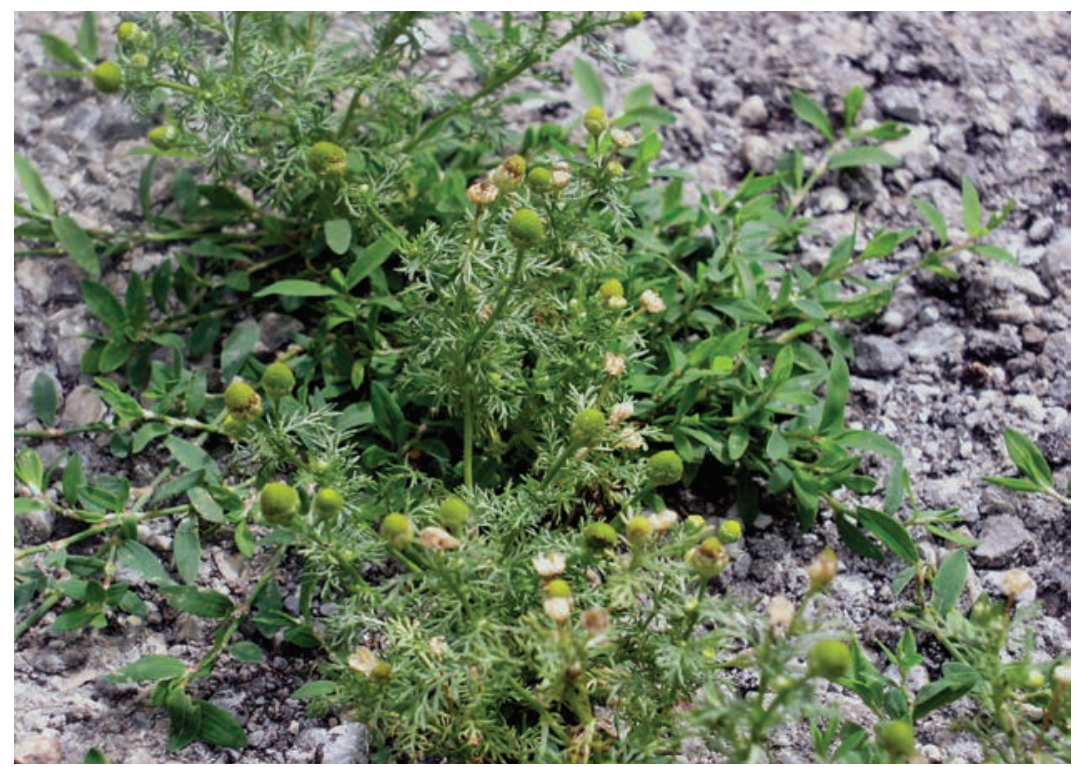

Slika 7: Kamilica ispred kuće Anke Šolić Tutanove u Šolicima; snimila Petra Kelemen, srpanj 2005.

Ljekovita svojstva kapule (luka) objasnila je Zdenka Pavelić Vranićeva iz Pavića: Onda mećalo se kad bi nešto ubolo pa se ono ugnojilo, onda kapulu metni, da se to razvali, ka provali ta kapula, da to izade taj gnoj van. E, kapulu. Ive Krmpotić Pićica iz Kuljića kazao je kako su se luk i češnjak koristili za tlak. Mara Krmpotić Brndina iz Veljuna navela je: To su babe da je luk dobar, da luk liječi od 9 rana, e, tako su vikale.

Biljke pod nazivima kopar (lat. Anethum graveoleus) i kimljen (lat. Carum caru) ${ }^{21}$ spomenuli su brojni kazivači, ponajprije navodeći kako se koristila $z a$ želudac, ${ }^{22}$ odnosno kod bolnog trbuha (sl. 8). ${ }^{23}$ Mira

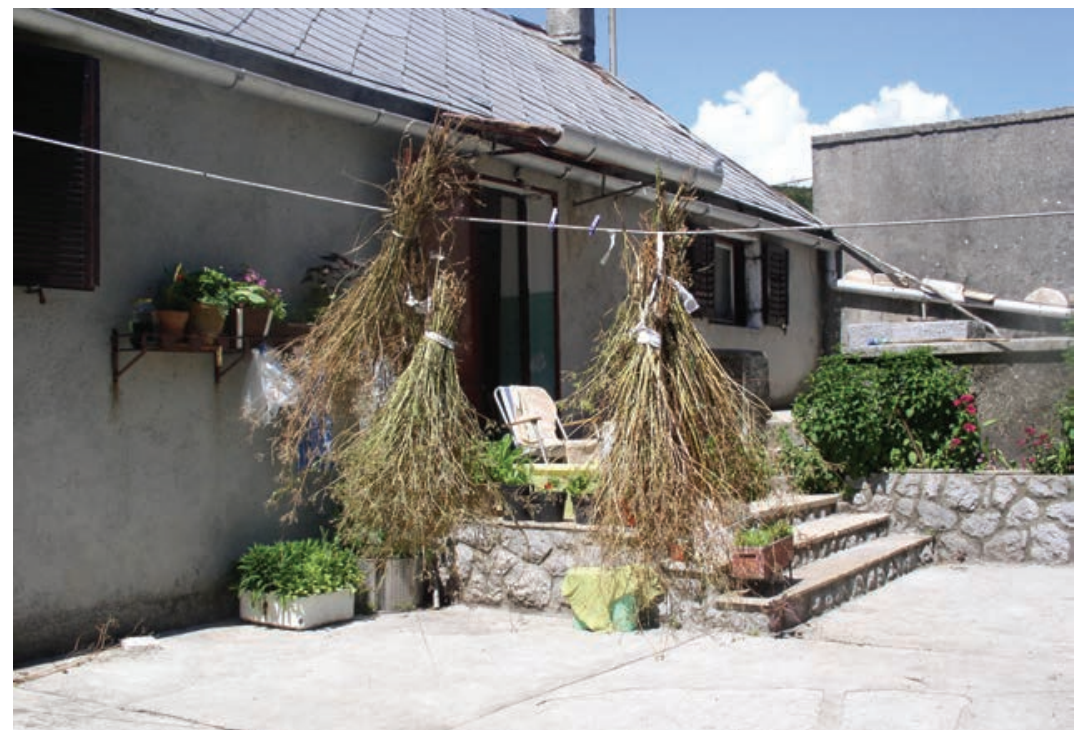

Slika 8: Kopar se suši ispred kúce Nade i Milana Prpić Terezinih u Krivom Putu; snimila Petra Kelemen, srpanj 2005.

21 Luka Krmpotić Brnde iz Veljuna i Zvonko Pavelić Dujela iz Serdara oba naziva koristili su kao istoznačnicu. Ove dvije biljke kazivači nedovoljno jasno razgraničavaju. Biljku pod nazivom kopar spomenuli su: Francika Šojat Babićeva, Šojatski Dolac; Marko Prpić Rus, Rusova Draga; Pavla Pavelić Cirilova, Pavelići; Mara i Luka Krmpotić Brndini, Veljun; Zlata Tomljanović Pešina, Krivi Put. Ivan Pavelić Jandra iz Serdara, Ivanka Krmpotić Šimunova iz Škobaca, Milan Krmpotić Zekonja iz Veljuna i Ive Krmpotić Pićica iz Kuljića biljku su nazvali kimljen.

22 Ljubica Prpić, Gorica; Anka Prpić, Gorica; Ika Pavelić Tomina, Pavići; Milan Krmpotić Zekonja, Veljun; Ive Krmpotić Pićica, Kuljići; Mara Krmpotić Brndina, Veljun; Zlata Tomljanović Pešina, Krivi Put; Ivanka Krmpotić Šimunova, Škopci.

23 Draga i Marko Tomljanović Rilčevi, Katići; Mara Krmpotić Brndina, Veljun; Nevenka Krmpotić Aneličina, Veljun. 
Tomljanović Ropetina iz Krivoga Puta navela je: Kopar za, taj kopar smo brali kad trbuh dite kad je bolilo, a slično je kazala i Marija Prpić Kavaričina iz Lucića: Na primer prije nije bilo čajeva, nije bilo ništa i kad bi dite malo bolija trbuščić il što, to se kuvalo za čaj, to se davalo malon ditetu.

Kopriva (lat. Urtica dioica) ${ }^{24}$ se, prema objašnjenju Milana Prpića Terezinog iz Krivoga Puta, koristila kod bolesti prostate i bubrega te kod masnoće. Ana Šojat Colaševa iz Francikovca navela je kako je kopriva dobra za prostatu, giht i reumatske bolesti. Zlata Tomljanović Pešina iz Krivoga Puta kazala je kako se kopriva koristila za mokraćne kanale.

Lipa (lat. Tilia platypylles) ${ }^{25}$ se, prema riječima Pavle Pavelić Ćirilove iz Pavelića, Ike Pavelić Tomine iz Pavića i Zvonka Pavelića Dujele iz Serdara, koristila kod prehlade, dok je Marko Tomljanović Rilac iz Katića naveo kako je ona bila za pluća, da bolje dišeš. Branko Tomljanović Ropeta iz Krivoga Puta kazao je da je lipa bila dobra za kašalj. Marija Prpić Vinina iz Veljuna objasnila je: A tako mišaj, to je bilo tobož za želudac, za sve, za svakakva. Milan Pavelić Vranić iz Pavića spomenuo je: Vidite još, ako izgori se od vruće vode kuvane, onda se isto upotrebljavala lipa. Od lipe kora isto, drugi sloj kore se struga i mliko. I to se privijalo $i$ isto da vidiš kako bi znalo zarest od toga. I najbrže isto. Lipa i... (...) To se miša s mlikon. E, i to se privija onda di se izgori. (...) Krpa bi se najvišse upotrebljavala lanena. Jer ima i predivo i lan, ali je lan puno bolji. Lanena krpa isto za stegnit na primer ko ima vene ili što. Ta krpa isto lanena puno pomaže. Što se god veća rana bila ili što, lanena se krpa upotrebljavala ta.

Za biljku pod nazivima majčina/majkina dušica (lat. Thymus serpyllum) ${ }^{26}$ Milka Prpić Jurina iz Mrzlog Dola, Mile Prpić Popić iz Popića i Ika Pavelić Tomina iz Pavića ${ }^{27}$ objasnili su da se upotrebljavala za želudac, a jedino je Marija Prpić Vinina iz Veljuna za majkinu dušicu navela kako se ona upotrebljavala za pluća.

Za stolisnik (sl. 9) je zabilježeno više naziva: mrmolj, hrmolj, rmelj, hajdučka trava, trava s mejašal mrgilja, stolisnik, sporiš (lat. Achillea millefolium). ${ }^{28}$ Nada Prpić Terezina iz Krivoga Puta kazala je kako se rmelj, hajdučka trava koristila za grčeve, te pridodala: To ja vidin da doktorica kad djecu boli trbuh, za grčeve, da to priporuća isto skuhat. Mara Tomljanović Isanova iz Krivoga Puta navela je kako je stolisnik, hajdučka trava za žuč, te pojasnila kako se ona naziva i trava s mejaša: Stolisnik, trava sa mejaša, a stare babe trava sa mejaša, jer na mejašu ona reste. Mnogi su kazivači potvrdili kako se ova biljka koristila kod želučanih tegoba. ${ }^{29}$ Mirko Prpić Cungo iz Krivoga Puta ispričao je: A ima, ima onaj stolisnik i ovo, ima ti trava dosta, ali taj stolisnik, meni je žena liječnik i ona ih preporučava tim babam stalno. Jer je to stvarno dobro. (...) Pa

24 Ovu su biljku spomenuli: Draga Tomljanović Rilčeva, Katići; Nada Prpić Terezina, Krivi Put; Marko Prpić Rus, Rusova Draga; Milan Blažević Trećak, Mrzli Dol (koji je govorio o soku od kopriva); Jure Tomljanović Ban, Šolići.

25 Lipu su spomenuli: Nada Prpić Terezina, Krivi Put; Josip Blažević Ivela, Mrzli Dol; Milka Prpić Jurina, Mrzli Dol; Ivan Pavelić Jandra, Serdari; Ivanka Krmpotić Šimunova, Škopci; Francika Šojat Babićeva, Šojatski Dolac; Mara Krmpotić Brndina, Veljun.

26 Ovu su biljku spomenuli: Anka Prpić i Ljubica Prpić, Gorica; Marko Tomljanović Rilac, Katići; Milan Prpić Terezin, Krivi Put; Mira Tomljanović Ropetina, Krivi Put; Mirko Prpić Cungo, Krivi Put; Marija Prpić Kavaričina, Lucići; Josip Blažević Ivela, Mrzli Dol; Milan Blažević Trećak, Mrzli Dol; Anka Pavelić Kuzmanova, Pavelići; Zdenka Pavelić Vranićeva, Pavići; Nevenka Krmpotić Aneličina, Veljun; Mara Krmpotić Brndina, Veljun; Ana Šojat Colaševa, Francikovac.

27 Ova je kazivačica upotrijebila naziv majkina dušica.

28 Ovu su travu spomenuli: Milan Blažević Trećak, Mrzli Dol (stolisnik); Josip Blažević Ivela, Mrzli Dol (sa mrgilja trava); Anka Šolić Tutanova, Šolići (mrmolj i trava s mejaša); Mara Krmpotić Brndina, Veljun (rmelj); Jadranka Tomljanović, Veljun (stolisnik); Milan Krmpotić Zekonja, Veljun (mrmolj); Ive Krmpotić Pićica, Kuljići (hrmolj); Ana Šojat Colaševa, Francikovac (stolisnik); Tome Špalj Cucin, Krivi Put (mrmolj; uz objašnjenje da je to književno stolisnik); Zlata Tomljanović Pešina, Krivi Put (sporišs, hajdučka trava i stolisnik), Branko Tomljanović Ropeta, Krivi Put (mrmolj, stolisnik, hajdučka trava).

29 Ana Šojat Colaševa, Francikovac; Marija Prpić Vinina, Veljun; Mira Tomljanović Ropetina, Krivi Put; Nevenka Krmpotić Aneličina, Veljun; Milan Krmpotić Zekonja, Veljun; Ive Krmpotić Pićica, Kuljići; Zlata Tomljanović Pešina, Krivi Put; Branko Tomljanović Ropeta, Krivi Put; Tome Špalj Cucin, Krivi Put; Francika Šojat Babićeva, Šojatski Dolac; Zdenka Pavelić Vranićeva, Pavići. 
za želudac, za... a čuj za te tegobe kad neko ima te, probavne. To i mi zovemo trava sa mrgilja jer obično raste ondje između dvi njive, na medi. Marija Prpić Kavaričina iz Lucića objasnila je kako se ova trava koristi za sve. To su se miješali prije. I malo kopra, malo mrmolja, malo metvice, malo majčine dušice, to se sve skupa miješalo i stavilo u jedan lonac $i$ isto se kuva čaj, a isto se kuvalo i posebno. Mogo se kuvat mrmolj sam, moga se kuvat kopar sam, moglo se sve pojedinačno i moglo je bit sve skupa. Josip i Milka Prpić Jurina iz Mrzlog Dola također su potvrdili kako je za sve bolove dobar. Ima ga jako puno i sad ga ima tu. Zlata Tomljanović Pešina iz Krivoga Puta objasnila je još jednu upotrebu ove biljke: Čajeve za reumu. Ovaj stolisnik, on je jako dobar za zglobove i za reumu i za kostobolju, za sve, da je jako dobar stolisnik.

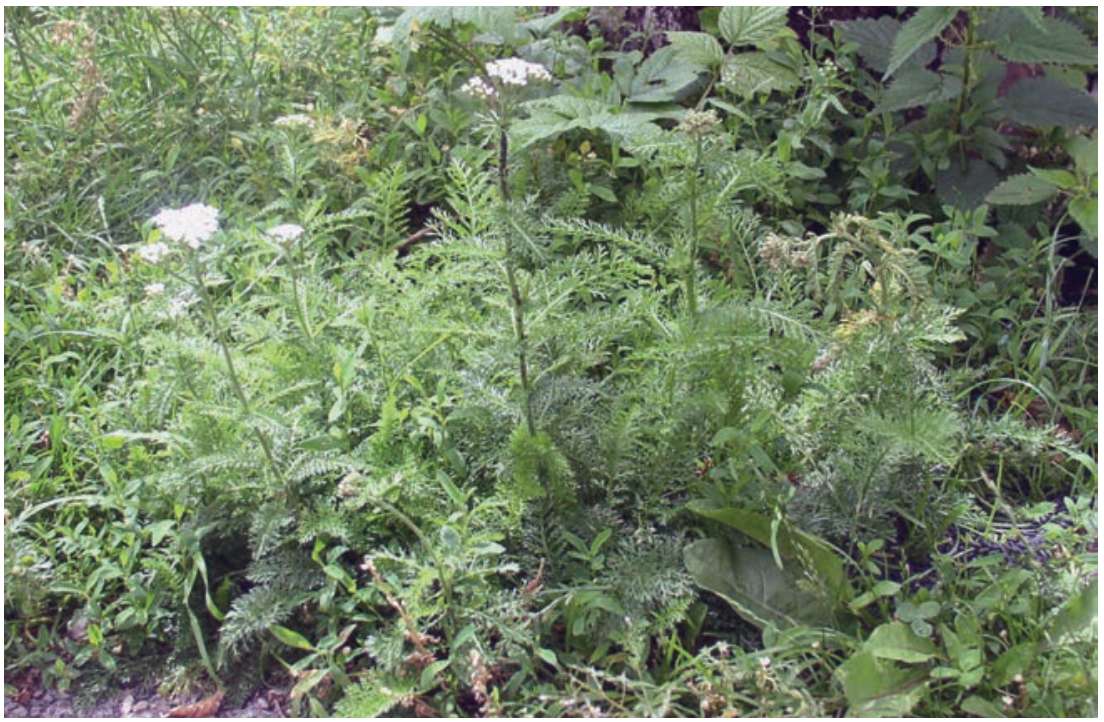

Slika 9: Mrmolj ispred kuće Anke Šolić Tutanove u Šolicima; snimila Petra Kelemen, srpanj 2005.

Za metvicu (lat. Mentha piperta) ${ }^{30}$ je Josip Blažević Ivela iz Mrzlog Dola rekao kako je dobra za sve. Za sve je metvica (sl. 10, sl. 11). Zdenka Pavelić Vranićeva iz Pavića, Zlata Tomljanović Pešina iz Krivoga

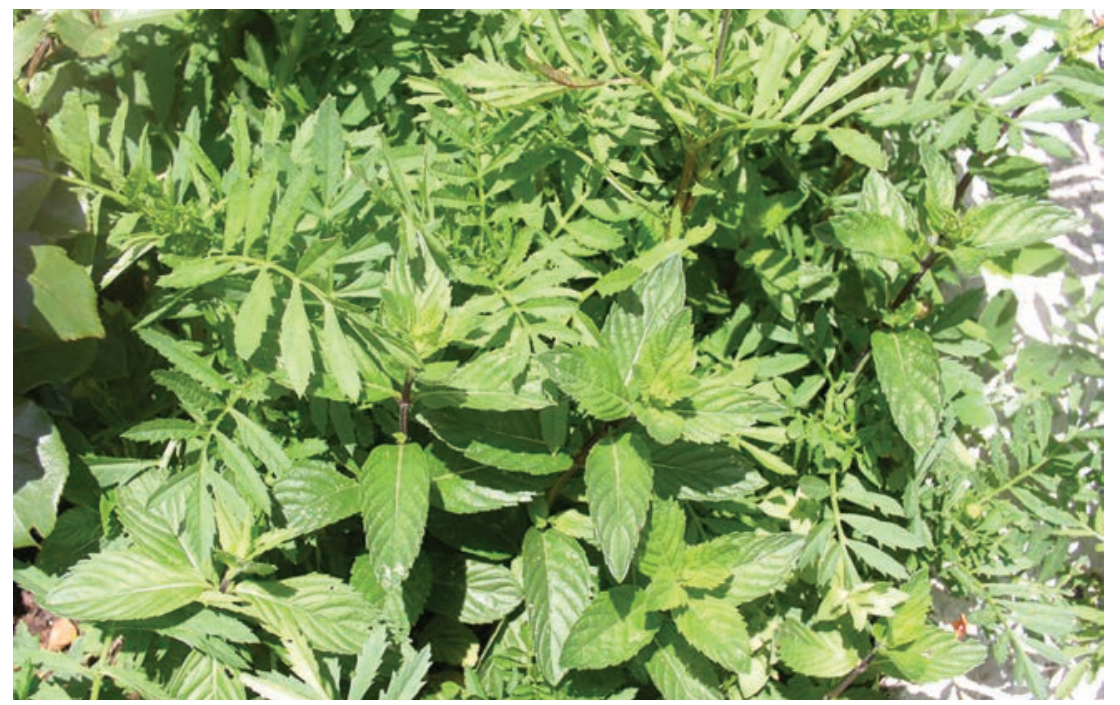

Slike 10: Metvica ispred kuće Milke i Milana Prpić Markinovih u Veljunu; snimila Petra Kelemen, srpanj 2005.

30 Ovu su biljku spomenuli: Draga i Marko Tomljanović Rilčevi, Katići; Nada Prpić Terezina, Krivi Put; Mira Tomljanović Ropetina, Krivi Put; Mirko Prpić Cungo, Krivi Put (kazivač je napomenuo kako postoji divlja i pitoma metvica); Marija Prpić Kavaričina, Lucići; Pavla Pavelić Ćirilova, Pavelići; Marko Prpić Rus, Rusova Draga; Zvonko Pavelić Dujela, Serdari; Nevenka Krmpotić Aneličina, Veljun; Luka (kazivač je napomenuo kako postoji divlja i pitoma metvica) i Mara Krmpotić Brndini, Veljun; Zlata Tomljanović Pešina, Krivi Put (kazivačica je govorila o domaćoj metvici). 
Puta i Marija Prpić Vinina iz Veljuna kazale su kako je metvica dobra za želudac, a Anka Šolić Tutanova iz Šolića kako se koristila za trbuh. Ivanka Krmpotić Šimunova iz Škobaca napomenula je kako postoji pitoma i divlja metvica te dodala: Od metvice ovako kad želudac boli, to su babe prvo kuhale čaj kad bi želudac bolija. Zlata Tomljanović Pešina iz Krivoga Puta pridodala je kako su čaj od metvice, ili kako su je još zvali, nane, žene pile za ublažavanje menstrualnih bolova. Milan Prpić Markin iz Veljuna kazao je kako je metvica dobra za čišćenje mokraćnih kanala i za bubrege.

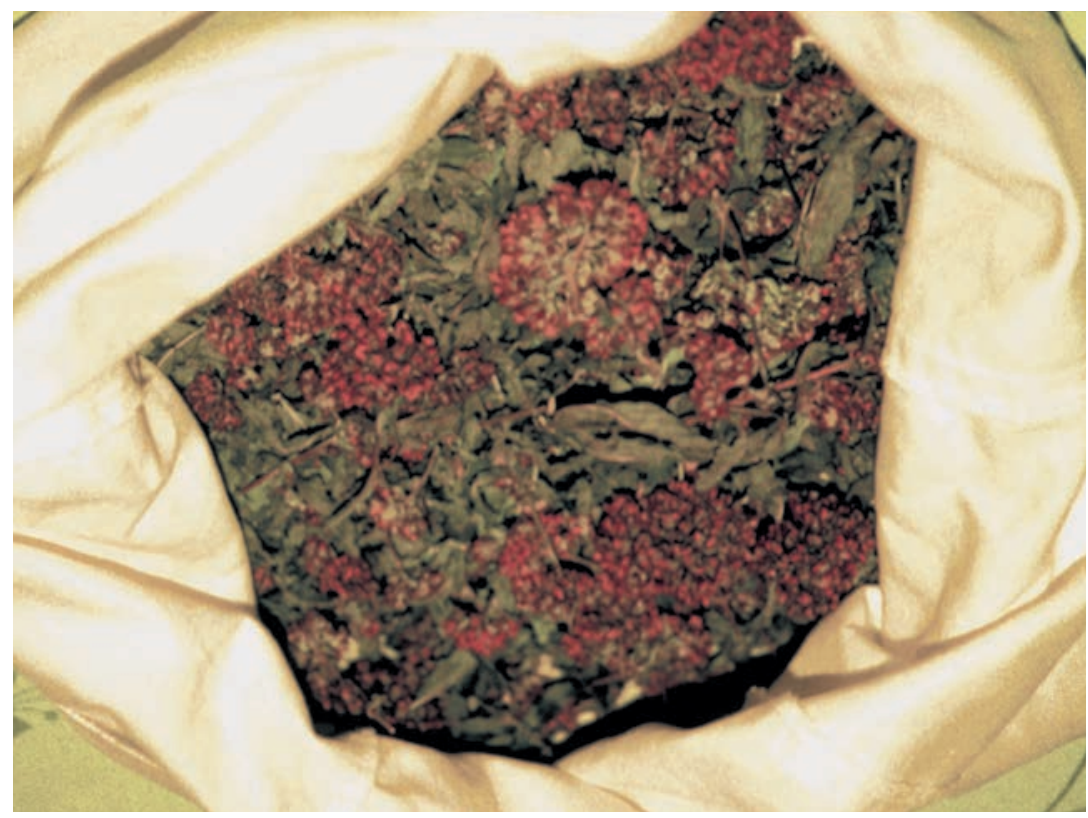

Slika 11: Sušena metvica, pripremila Ana Šojat Colaševa u Francikovcu; snimio Augustin Perić, studeni 2007.

Upotrebu nevena (lat. Calendula officinalis) spomenula je Ana Šojat Colaševa iz Francikovca, opisujući postupak dobivanja nevenove masti (sl. 12, sl. 13): obična domaća mast i onda se ove žute rožice... nevenovi listicí, šafrana, 2 dcl. I to van lagano krčka na šparetu dok ovako požuti. I to za rane, za vene, za kožu. (...) Mast se lagano kuha dok van ne postanu listići, dok ne postane svijetložuto. Kazivačica je navela kako je taj recept negdje pročitala, što govori o tome kako se naslijeđeno znanje dopunjavalo onim iz knjiga ili stručnih časopisa.

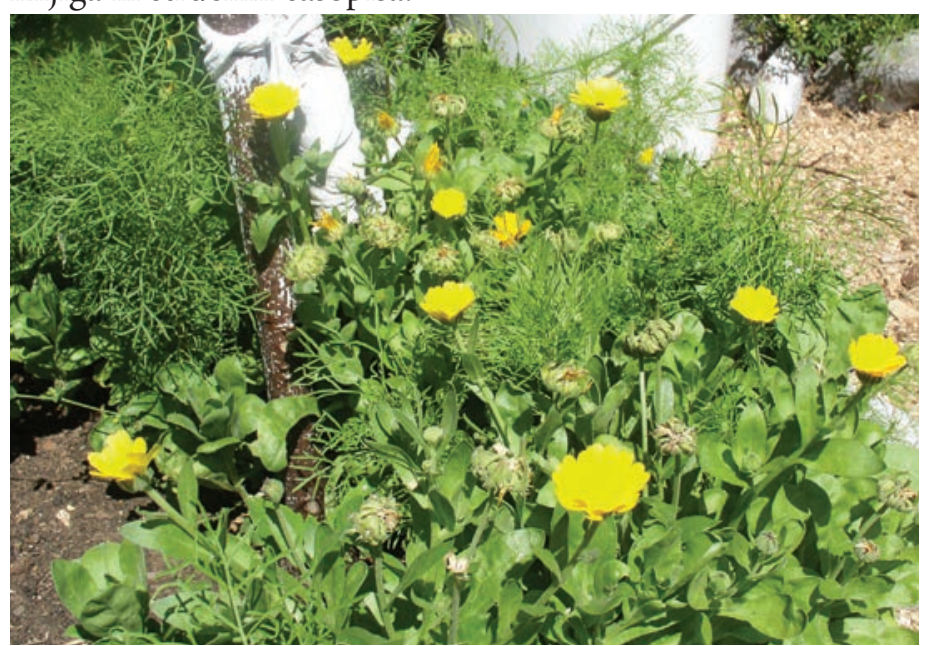

Slika 12. Neven u dvorištu kuće Ane Šojat Colaševe iz Francikovca; snimila Petra Kelemen, srpanj 2007.

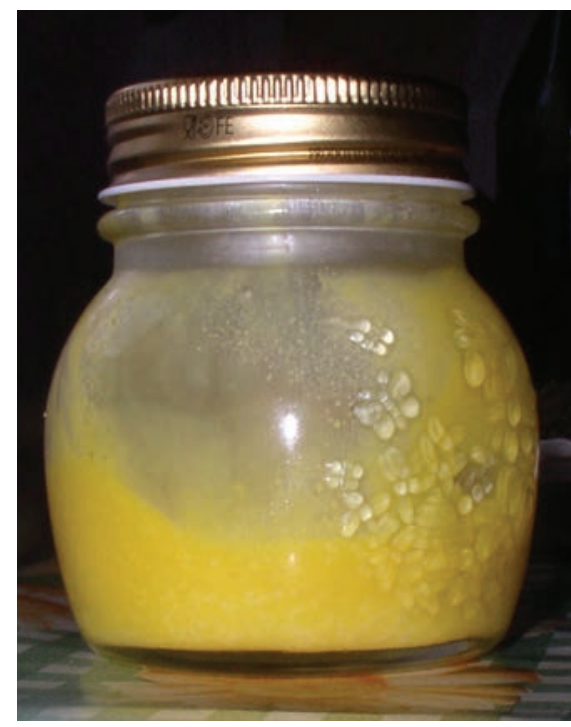

Slika 13: Nevenova mast-pripravila Ana Šjat Colaševa iz. Francikovca; snimila Petra Kelemen, srpanj 2005. 
Za biljku, čije su ime pojedini kazivači vezali uz njezin specifičan oblik, zabilježeno je više naziva: petoprsta trava, trava pet prsta, trava od pet prsta, posik, trava od posika, trava od posjeka (sl. 14). Mira Tomljanović Ropetina iz Krivoga Puta kazala je da se ova trava koristila kod posjekotina: Je, to moj svekar meća, ta petoprsta neka travca, to je isto bilo, ja ne znan da je to isto vredilo. No, svekru ta trava ipak nije pomogla: A nije, mora je ić u bolnicu. Zdenka Pavelić Vranićeva iz Pavića rekla je: E, kad bi se posikli, nadi travu od pet prsti. Milan Pavelić Vranić iz Pavića ovu je travu nazvao trava od pet prsta i objasnio: Pet listića ima. Jedan van je list vako, onda sad ima ona 5 listića rastavljenih. Od te trave najbrže zaraste. Luka Krmpotić Brnde iz Veljuna kazao je kako se trava od posika upotrebljavala kod posjekotina. Milan Krmpotić Zekonja iz Veljuna i Ive Krmpotić Pićica ovu su travu nazvali posik i također potvrdili da se upotrebljavala kod posjekotina. Milan Prpić Markin iz Veljuna kazao je da se trava od posjeka ${ }^{31}$ stavljala na ranu te dodao: $D a$. To se mećalo. A zvali su je babe trava od pet prsta. Pet prsta je imala. (...) Listića. To je na ranu se mećala.

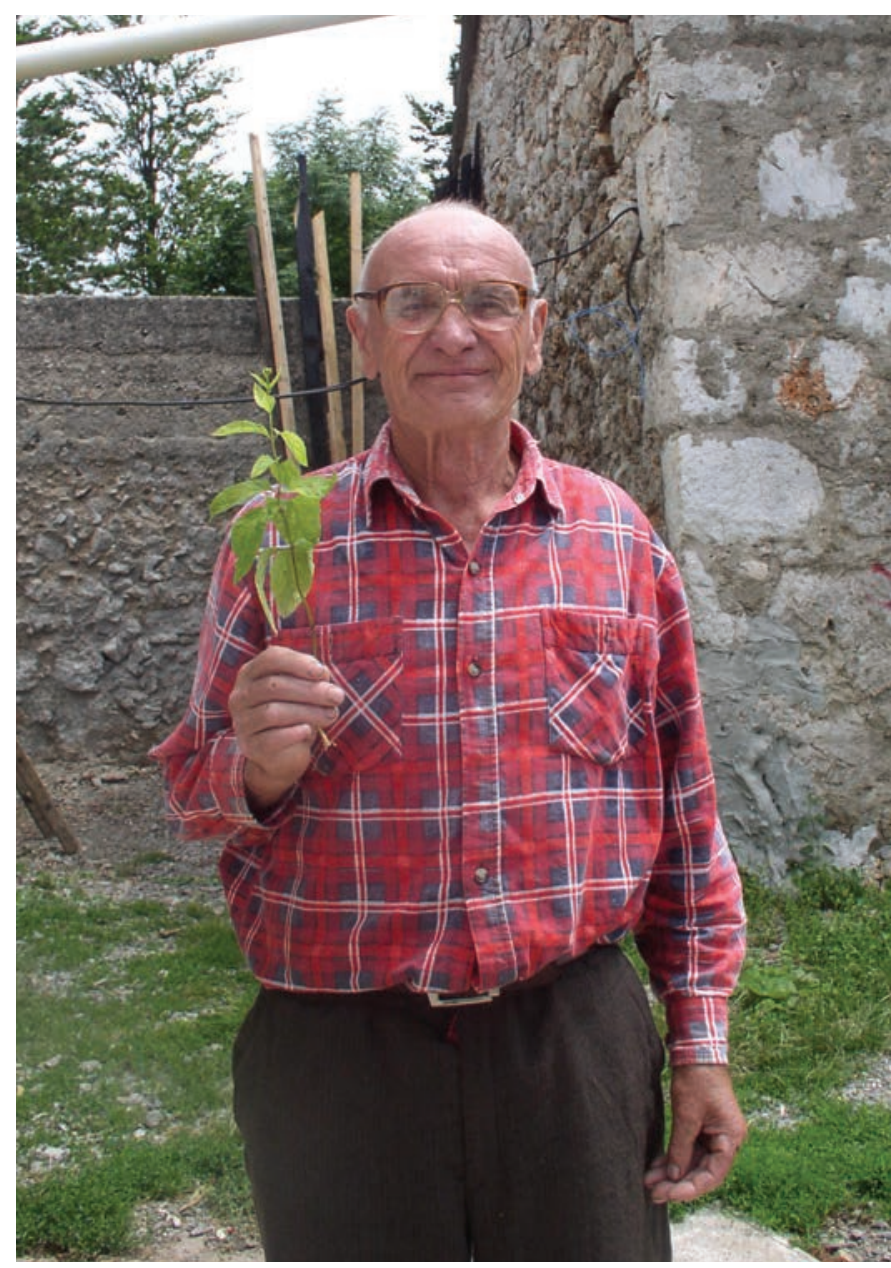

Slika 14: Kazivač Milan Krmpotić Zekonja iz. Veljuna pokazuje travu posik; snimila Petra Kelemen, srpanj 2005.

Za vrisak (lat. Calluna) ${ }^{32}$ je Pavla Pavelić Cirilova iz Pavelića kazala kako je vrisak jako dobar ko je plućno bolestan, on ujesen cvita, plavi cvit; dok je Marica Krmpotić Migečeva iz Veljuna rekla kako je on dobar za bronhitis. Mara Krmpotić Brndina iz Veljuna pojasnila je: Vrisak bio za svaku vako koju upalu, to svako jutro smo kuvali, navečer. Ana Šojat Colaševa iz Francikovca kazala je kako je vrisak jako zdrav za žene, za menzis, za bolove.

Uz nabrojane biljke, samo su pojedinci potvrdili upotrebu pojedinih biljaka. Tako je Milan Prpić Markin iz Veljuna spomenuo bubrežnjak: To je raste ovako jedna stabljika, njegova mala šuplja kao mjehurić na svakon onon. To je za otvaranje vode, mokraće, za bubreg. Nevenka Krmpotić Aneličina iz Veljuna navela je kako se češnjak upotrebljavao kad je čovjek prehlađen. Ive Krmpotić Pićica iz Kuljića kazao je kako su češnjak i luk bili dobri za tlak. Anka Prpić, Grgo Prpić Miškec, Ljubica Prpić i Stjepan Prpić Stipina iz Gorice rekli su kako je pekmez od drinjula bio dobar za proljev, a Stjepan Prpić Stipina pridodao: To je jedna bilja koja možda spada u najzdravije biljke. Ive Krmpotić Pićica iz Kuljića kazao je kako je drin dobar za proljev. Josip Blažević Ivela iz Mrzloga Dola naveo je kako se gavez upotrebljavao za liječenje ovaca: Onda znan, mi smo imali ovce, zločesta je bila jedna, ja san bacio kamen i slomio sam joj nogu, došla je lijepo doma na tri i tata je gavez, trava neka, je na to lijepo metnija, dvi daščice i ovca za mjesec dana na sve četiri. Zabilježena su i kazivanja o ljekovitim svojstvima hrastove kore. Nada Prpić Terezina iz Krivoga Puta prisjetila se: Samo

31 Isti je naziv upotijebila i Mara Krmpotić Brndina iz Veljuna.

32 Ovu su biljku spomenule i Nada Prpić Terezina iz Krivoga Puta i Zdenka Pavelić Vranićeva iz Pavića. 
smo od hrasta radili jednon kad je kravu noga bolila, neśto otekla joj bila. Pa su rekli od hrasta koru kuvat pa mećat onu vodu. I jesmo i to se dobro. (...) Kora i onda ona voda mećala se. Milan Prpić Terezin objašnjava: Obloge oko noge. Jednako je tako Milan Pavelić Vranić iz Pavića naveo: I hrastova kora se isto upotrebljavala za blago. Goveda ako bi imala proljev ili što, onda isto rastovu koru, samo je trebalo topit nekoliko dana. (...) E, u vodi. I to isto gornji sloj skinit, pa onaj drugi sloj. Milka i Milan Prpić Markinovi iz Veljuna jedini su spomenuli kopitnjak. Milan je naveo: Onaj sto ima cvijet ciklamu. Njegov je gornji dio lista zelen, donji je crven. Gornji dio mu je ljekovit, a donji otrovan. Onda kad bi se napravija čir, babe donesi jedan list $i$ metni ga na čir (...), odma za jednu noć od prosiče čir. Jer on otrovan. Pri tom se postupku na čir stavljala donja strana lista. Anka Pavelić Kuzmanova iz Pavelića kazala je kako se $\boldsymbol{m l i c ̌ i k a}^{33}$ upotrebljavala za čir i poriz što je znala još kazivačicina baka: I čir, kad se ima čir, ne treba ić doktoru. (...) Ta trava onda i pomaže se ili maslacom ili masti, pomaže se i za pol sata ona provali čir. I onda isto poslije ga liječi. (...) A mličika. E, to je prije moja baka još znala. Privija. Pomaže i stavlja se ona strana koja je bila donja i opet se ovako stavlja isto. Milan Prpić Terezin iz Krivoga Puta kazao je kako se biljka pelin koristila za apetit. Mara Krmpotić Brndina iz Veljuna navela je kako se sliz koristio za bubrege. Francika Šojat Babićeva iz Šojatskoga Dolca spomenula je pekmez od šipka: Peci pekmez od šipka, to bilo dobro za dicu, kad bi bila dica proljev, pa ispeci pekmez i dici daj. Nevenka Krmpotić Aneličina i Marica Krmpotić Migečeva iz Veljuna kazale su kako se trava štavelj koristila za proljev, a Nevenka je pridodala: Ja ovoga iman uvik u kući. Milan Pavelić Vranić iz Pavića objasnio je ljekovito svojstvo tise: Još ima tisa se zove, ta trava, isto taj njezin list, ona stisne ranu. Jer ove druge pojedine trave čiste ranu pa još razvali na primer. A ta tisa, ona stisne ranu tako da se malo pozna di je posičeno. E. (...) Moralo se samo očistit tobože toplon vodon ili s čin da ne bi ostalo prljavo. Čovik kad radi ostane prašine i svega, to najprije odstranit i onda. Jer nije bilo prije ni alkohola ni ništa. (...) E, vidite ode, to san ja sikiron zasika, al je to bilo, to bi mogo prst unutra vako odma u ranu. I to je od te tise se stislo i zareslo. Samo je to već odavna. Milan Prpić Markin iz Veljuna naveo je upotrebu žestike: A za reumu je bila neka, crvene bobice imala na sebi, mi smo je zvali žestika. Pa imala crvene bobice. To je vražji kruh kad se š njon namaži za reumu. Te bobice istisneš, napraviš kao sok. Onda se s tin maži. Onda se s tin maži svrab u ratu, šuga. Svaki rat odma dobije, najprije dobije uši, onda šugu. (...) S tin su onda babe na selu mazale, ličile. Za reumu isto s tin liječi, samo manje se moralo mazat, to gori, peče to ko vrag. Onda vrag peče pa misliš da je dobro, vrag zna da je dobro. Nego trpi čeljade jadno.(...) Malo mlijeka pa da mlijeko zadrži onu gustoću na koži, da više ostane vode na duže vremena. Pomiješa se malo pa se namaži. Draga Tomljanović Rilčeva iz Katića kazala je kako se za bradavice upotrebljavala tičja trava ${ }^{34} i$ onaj crni puž. To je bilo sve ono starinski domaće. (...) Crni puž, namaže se š njim. Ivan Prpić Kavarica iz Lucića rekao je kako se za bradavice koristio sok smokava: To od smokve, kad je smokva zelena, pa onda naberi smokve pa istisni. (...) Onaj sok, e. Samo od zelene. Vezano uz uklanjanje bradavica Zdenka Pavelić Vranićeva iz Pavića ispričala je: Eja san imala ovako bradavice ovako tu i ovako ode. I meni to smetalo, ja plivila, znate, povrće, plivila, u povrći ima svakakve trave...(...) Jedanput ja vidin to kad san oplila, nema bradavice, nikakve, dvi su bile, ostalo ciisto, bez bradavice. Valda bila neka trava i to je onda valda skinila. I posle nikada više; dok je njezin suprug Milan pridodao da su se bradavice i rane mazale biljkom koju oni nazivaju slatkiš.

Zdenka Pavelić Vranićeva i Kata Pavelić Burgijina iz Pavića spomenule su ljekovito djelovanje prašine, bršine drveta koja se koristila umjesto pudera ili kreme kod upala: Prije ono kad bi se dite zailo, mi rečemo zailo, ispod ruku ili po guzi, onda bi bršine ove, jel bršina, ovo drveta što crv vrti. Ja znan, moja baba. Onda bi ton bršinon zasipali ili sa kavon. (...) Kao opekla ga voda između nožica.

Milan Prpić Terezin iz Krivoga Puta spomenuo je djelovanje kukurijeka koji nije ljekovit, ali se njegovo djelovanje ipak koristilo u pojedinim situacijama: Pa da. Pa bilo je, trava, samo je onaj kukurijek. Kad je

33 Francika Šojat Babićeva iz Šojatskoga Dolca nije znala za što se upotrebljavala mličika: Bila mličika, ona visoka bila, bila lipa za brat, al to nismo mi upotrebljavali, bila samo ovako. Također, ljekovito djelovanje ove trave nisu poznavale Marija Prpić Vinina iz Veljuna ni Nevenka Krmpotić Aneličina iz Veljuna.

34 Ivan Prpić Kavarica iz Lucića ne poznaje djelovanje tičje trave te napominje: To nismo mi upotrebljavali za niš. 
treba ić u vojsku, on je stavija, tako da ljudi čak nisu išli u vojsku, i to su znali. Da mu se razdrije noga, to su ljudi znali upotrijebit to, metnit na nogu i tako da je to. (...) Natekla i rana. A ovde su opet imali ljekovito to bilje i od puha mast i posle kad bi njega onesposobilo, onda se brzo izliječi. Opet on uspije da ne služi vojsku. ${ }^{35}$ Kazivači su često u razgovoru kao poznat i raširen lijek spominjali lik za konja. ${ }^{36}$ Većina ih je objasnila kako se lik koristio kod bolesti zvane kotunar, ${ }^{37}$ dok su pojedini pojasnili kako se radi o prehladi. ${ }^{38}$ Josip Prpić Jurina iz Mrzloga Dola ukratko je objasnio: Lik. To se uvlačilo doli pod vrat. To je jedno stablo niskoga rasta koje ima na sebi koru neku kao žilavu, al neko meso je ima između drveta i kore, to je bio taj lik. I onda ako je konj ima neki zvani kotunar se zva, to je bila prehlada. To je bila zvana bolest, dijagnoza. Onda kožu mu probuši i provlači mu taj kotunar tu kožu ostavi unutra $i$ ta koža bi povlačila onaj gnoj iznutra dok bi se gnojilo. I tako bi konj ozdravio.

Milan Pavelić Vranić iz Pavića ispričao je: E toga ima i sada tude. Konj kad bi ima kotunar, njemu oteci prsi ili oko vrata ili sve, onda se na prsi doli di komot iđe, ispod komota jošte, bila je igla velka, na primer kad bi šija štep-deku, onako. Onda su toga lika, gornja se korica skine, onda lik ostane, bija čist. I onda se to uvuče na tu iglu, ali ne sami, onda još ostriže se od repa il od grive, njegove dlake one, jer to bi konj sam zubima $i$ vezalo se, vrića se vezala. I to stoji, i iscuri konju, to je ćudo jedno kolko bi curilo. Onda se vaik mora pomicat mu da ne bi se zatvorila škulja, kud je lik vuče. Svaki nekolko sati se povuče lik, okruži se, jer lik se uvuče i sveže se. Baš u prsi se, ovako par centimetara, e, i s onom dlakon se sveže tu. I onda se vaik pomiče. I to bi konju sve izvuklo. Jer konj zna isto ozepsti, prizepsti i koješta. I to se najedanput sabere i počne ga gušit skoro. I kad se to izvuče, isto za desetak, petnaest dana konj ozdravi. E stalo je, po 15 dana je znalo stat. (...) Ma ako je vidi da treba joste, onda onaj baci lik pa se drugi metne.

Stjepan Prpić Stipina iz Gorice, Mira Tomljanović Ropetina iz Krivoga Puta i Mirko Prpić Cungo iz Krivoga Puta uz liječenje konja spomenuli su veterinara, odnosno čovjeka koji je poznavao taj postupak. Tako je Stjepan Prpić Stipina ispričao: Mogu vam ispričat jednu glupu tradiciju, bio je tu veterinar, bilo je puno konja, on je bio kao liječnik konja. Onda je on, recimo, neka je bila lik, otrovna biljka, onda je on od te biljke odrezo kore. To probuši tu konju i onda on uvuče unutra $i$ onda on gnoji unutra, otrovanje on dobije. Tobože on bio doktor, onda on reko da ima trentouno konj, njegov izraz, 31, on je tobože izraz taj ima, kao da je on latinski doktor. Mira Tomljanović Ropetina i Mirko Prpić Cungo iz Krivoga Puta spomenuli su Marka Šeku iz Matića. Mira Tomljanović kazala je: I to bi u prsa to uvuklo, taj jedan je tu samo zna, dol selo Matići. I onda je tako, posle samo veterinari, kad je on umra, više to niko nije radija, samo veterinari. (...) Nadimak je ima Marko Šeko. A ja san bila još, a nazad 50 godina i više. (...) Pa mislin iša je to po selu pomoć kad bi zvali bi ga. Mirko Prpić Cungo se prisjetio: Imali smo veterinara, on ima jednu svoju vako poštapalicu, kaže, "Ajde konj mi bolestan, odi vidi". To je bio čovjek, ovako nadriliječnik, ovo vako, što vam dođe, kaže "E, kasno si me zva, al ja ću poduzet sve, ako uspije dobro je”.

Uz ljekovito bilje i njegova ljekovita svojstva, kazivači su se prisjetili i korištenja meda i zemlje ilovače kod pojedinih bolesti. Tako su Nada i Milan Prpić Terezini iz Krivoga Puta potvrdili da se med koristio

35 Kata Pavelić Burgijina i Zdenka Pavelić Vranićeva iz Pavića poznaju kukurikavac, no Kata je kazala: A šta ja znan, ona baš néce je ni blago ni ništa. Ona jako da je žuka i neće je ni blago ni ništa.

36 Ovaj oblik liječenja naveli su: Stjepan Prpić Stipina, Gorica; Grgo Prpić Miškec, Gorica; Ljubica Prpić, Gorica; Mira Tomljanović Ropetina, Krivi Put; Mirko Prpić Cungo, Krivi Put; Milan Blažević Trećak, Mrzli Dol; Josip Prpić Jurina, Mrzli Dol; Ika Pavelić Tomina, Pavići; Mile Prpić Popić, Popići; Ivan Pavelić Jandra, Serdari; Nevenka Krmpotić Aneličina, Veljun; Milan i Zdenka Pavelić Vranićevi, Pavići; Branko Tomljanović Ropeta, Krivi Put. Ika Pavelić Tomina iz Pavića jedina je navela kako su od ove bolesti mogli oboljeti i magarci.

37 Milan Pavelić Vranić, Pavići; Mira Tomljanović Ropetina, Krivi Put; Josip Prpić Jurina, Mrzli Dol; Branko Tomljanović Ropeta, Krivi Put; Ivan Pavelić Jandra, Serdari. Mile Prpić Popić iz Popića kazao je kako se lik, kotunar stavljao u prsa. Mirko Prpić Cungo iz Krivoga Puta i Nevenka Krmpotić Aneličina iz Veljuna upotrebljavaju naziv gotunar.

38 Mira Tomljanović Ropetina, Krivi Put; Josip Prpić Jurina, Mrzli Dol; Mile Prpić Popić, Popići. Nevenka Krmpotić Aneličina iz Veljuna jedina je navela kako su konju natekla prsa od tumora. 
kod prehlade i gripe, dok je Nevenka Krmpotić Aneličina iz Veljuna kazala kako je med bio dobar za kašalj. Luka Krmpotić Brnde iz Veljuna spomenuo je kako se med od vriska i kadulje koristio za pluća, a njegova je supruga Mara nadodala: To su babe najvolile. Josip Prpić Jurina iz Mrzlog Dola kazao je: A med kao med je stvarni lijek, pri čemu je najkvalitetniji med od vriska. Milan Prpić Markin iz Veljuna objasnio je kako se med mora uzimati u malim količinama: kolko god dobar, toliko je štetan ako ćeš ga više uzet. Za želudac, ko nema probavu, ne smi se, on je težak. A inače je ljekovit. Za pluća većinon.

Nada Prpić Terezina iz Krivoga Puta spomenula je ljekovito djelovanje ilovače: Za obloge su ljudi mećali za reumu. Kopala se ilovača, gnjila mi kažemo, i onda se znala kuvat sa ostikon, miješat i kuvat i mećat po zglobovin i tako, to da je pomagalo. Mara Krmpotić Brndina iz Veljuna potvrdila je da je ilovača bila dobra za reumu, ali je ona sama nikad nije upotrebljavala.

\section{2. BILJNE I ŽIVOTINJSKE MASTI}

U potrebu puhove masti potvrdilo je više kazivača. ${ }^{39}$ Njezino ljekovito djelovanje vezivalo se uz više povreda: tako su pojedini kazivači naveli kako se ona koristila za rane, ${ }^{40}$ neki su objasnili da je bila dobra za posjekotine, ${ }^{41}$ dok su drugi objasnili kako se koristila kod opeklina ${ }^{42}$. Mile Prpić Popić iz Popića kazao je kako je od puha mast najzdravija, pridodavši da se ta mast radi još i danas, no jako je skupa, jedan kilogram košta petstotinjak kuna, a od jednog se puha dobije tek dvadesetak kapi. Josip Blažević Ivela iz Mrzlog Dola također se prisjetio obitelji koja je ponajviše izrađivala mast: $D a$, da, ove kuće jedan Blažević, to su bila dva brata i sestra (...) A on ima po par kila masti od puhova, on je hvatao puhova strašno i da je strahovito mast dobra za rane. I to je čuva i kad bi nekome trebalo, to se kod njega moglo nać. Tako smo ih rado hvatali i jeli. Nada Prpić Terezina iz Krivoga Puta objasnila je kako su oni suseljani koji su imali tu mast rado davali drugima, donosili kad bi se nešto dogodilo. Više su ljudi bili vezani.

Marija Prpić Vinina iz Veljuna ispričala je kako se spravljala mast od jazavca, ${ }^{43}$ i to samo od vrste koja se nazivala prasetnjak. ${ }^{44}$ Kazivačica je, međutim, napomenula kako su to radili ljudi starijih generacija: $A$ prvo su još više. Na primer, moj otac još više neg ja. Ljudi su s tim još više baratali neg danas. Na primer, ja kad sam bila, onda više se išlo $k$ doktoru.

O spravljanju masti za svrab najviše su kazivali Josip Blažević Ivela i Milan Blažević Trećak iz Mrzloga Dola. ${ }^{45}$ Naime, baka Milana Blaževića radila je tu mast, a on je poznavao i sastojke koji su se upotrebljavali: Mast za svrab. Ima jedna stabljika koju smo mi zvali žestika, onda je tu dodavala nešto sumpora i ne znan što je za viskozitet, koju je mast dodavala, običnu ovako mast radi viskoziteta. I bez obzira na to, recimo onda je bilo puno toga $i$ svraba $i$ sve, tri puta se namaži i nestalo ga je. (...) Dva mjeseca mene vuče i stvarno tvrde mi surab jesi surab, ja najprije doktoru, a ona uporno turdi da je. Ajd dobro, kad mi dala mast, od nožnog palca dovde sve se... Dva mjeseca. Na kraju kad se završilo to i ona meni daje odjavnicu pošto san radio, ja kažem, doktorice, znate šta? Šta? Reko, moja baba nepismena bila i kad je napravila mast za surab, tri puta se

39 Mira Tomljanović Ropetina iz Krivoga Puta ne poznaje djelovanje masti iako zna da se radila. Kazala je kako se to više nosilo iz apoteke.

40 Nada Prpić Terezina, Krivi Put; Mile Prpić Popić, Popići; Marko Prpić Rus, Rusova Draga; Ivan Prpić Kavarica, Lucići; Ika Pavelić Tomina, Pavići; Pavla Pavelić Ćirilova, Pavelići (kazivačica je jedina navela kako je mast bila dobra za reu$\mathrm{mu}$ ). Ivan Pavelić Jandra iz Serdara zna kako se ta mast upotrebljavala za nešto, ali se nije mogao sjetiti za što. Prisjetio se samo kako su njome mazali kad bi volovima stavljali jaram.

41 Ivan Prpić Kavarica, Lucići; Milan Blažević Trećak, Mrzli Dol.

42 Mirko Prpić Cungo, Krivi Put; Josip Prpić Jurina, Mrzli Dol; Zdenka Pavelić Vranićeva, Pavići.

43 Mast od jazavca potvrdio je i Luka Krmpotić Brnde iz Veljuna, no nije se prisjetio pojedinosti.

44 Druga vrsta se naziva pasjak, od nje se nije pripremala mast; lov puhova obradila je Marijeta Rajković u tekstu Tradicijski i suvremeni lov u prvom svesku Monografije.

45 Spravljanje masti za svrab potvrdio je i Josip Prpić Jurina iz Mrzlog Dola. Nevenka Krmpotić Aneličina iz Veljuna potvrdila je kako su se u mast stavljali sumpor i žestika, no nije se mogla prisjetiti trećeg sastojka. 
namaza, nestalo, vaše traje dva mjeseca. Još je ona imala, ta baka moja, to je, recimo bradavice bez ičega, ona nije mazala ni ništa, al bradavice kolko ljudi dolazilo $k$ njoj $i$ šta je ona radila to nikome nije, čak ni materi nije prenesla. Ona to kako ni zašto, to nikada ne znam. Samo znam da je tu nešto prčkala po tom i ono nešto došla tamo, za dva tjedna već nestane svega. Tu su, ljudi su se snalazili svakako. Ivan Prpić Kavarica iz Lucića također se prisjetio Milanove bake Marije Blažević Ivela koja je, kako je kazao, jedina znala spravljati mast za svrab.

\section{LIJEČENJE UPALE OČIJU I UŠIJU TE SNIŽAVANJE POVIŠENE TJELESNE TEMPERATURE}

$\mathrm{K}^{\mathrm{o}}$

od upale, oči su se ispirale čajem od kamilice. ${ }^{46}$ Marija Prpić Kavaričina iz Krivoga Puta kazala je da e oko ispiralo vodom.

Kad bi došlo do upale uha, primjenjivalo se, prema riječima kazivača, više načina liječenja. ${ }^{47}$ Pojedini su naveli kako se pritom ponajviše koristilo ugrijano jestivo ulje koje bi se kapnulo u uho. ${ }^{48}$ Zlata Tomljanović Pešina iz Krivoga Puta prisjetila se: Da, da, mene kad su uha boljela, sada ne daj, Bože, da se to primijeni, moja pokojna mama, ona je malo u žličici zagrijala ulja tako da bude mlako, ne vruće, i meni je znala kapnuti ulja, mene su uha prestala boljet. A sada, kakvo ulje, kakvo uho, to se sad ne smi, niko neće ni pokušat. Mara Tomljanović Ropetina iz Krivoga Puta, Zlata Tomljanović Pešina iz Krivoga Puta i Zvonko Pavelić Dujela iz Serdara kazali su kako se za liječenje uha koristio čuvarkuća (sl. 15). ${ }^{49}$ Milan Prpić Markin iz Veljuna objasnio je: Od njega kad najjače čovika uho zaboli. Dvi kapi samo izlit u uho i gotovo.

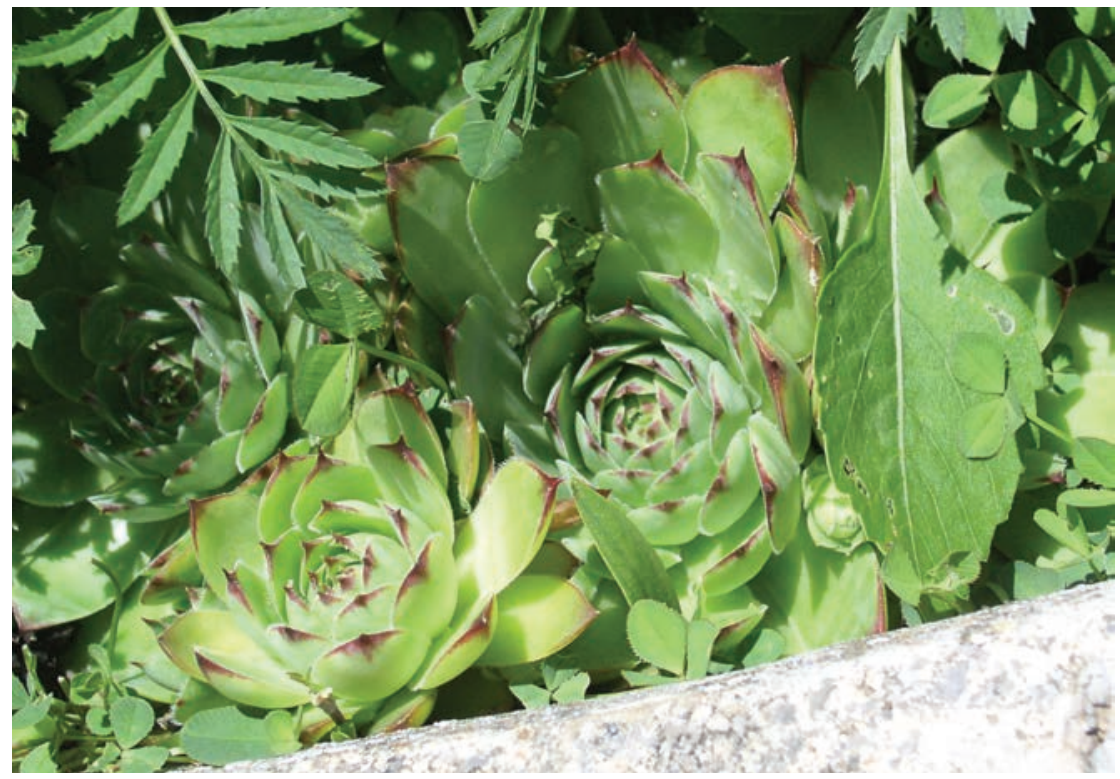

Slike 15: Cuvarkuća ispred kuće Milke i Milana Prpić Markinovih u Veljunu; snimila Petra Kelemen, srpanj 2005.

46 O liječenju upale očiju govorili su: Nada Prpić Terezina, Krivi Put; Marija i Ivan Prpić Kavaričini, Krivi Put; Ika Pavelić Tomina, Pavići; Anka Šolić Tutanova, Solići.

47 O liječenju upale uha govorili su: Stjepan Prpić Stipina, Gorica; Nada Prpić Terezina, Krivi Put; Mara Tomljanović Isanova, Krivi Put; Mira Tomljanović Ropetina, Krivi Put; Marija i Ivan Prpić Kavaričini, Krivi Put; Josip Prpić Jurina, Krivi Put; Zvonko Pavelić Dujela, Serdari; Marija Prpić Vinina, Veljun; Zdenka i Milan Pavelić Vranićevi, Pavići; Mara Krmpotić Brndina, Veljun.

48 Ovaj postupak potvrdili su: Stjepan Prpić Stipina, Gorica; Marija i Ivan Prpić Kavaričini, Krivi Put; Josip Prpić Jurina, Krivi Put; Marija Prpić Vinina, Veljun; Mara i Luka Krmpotić Brndini, Veljun; Zdenka i Milan Pavelić Vranićevi, Pavići; Mara Tomljanović Isanova, Krivi Put; Zlata Tomljanović Pešina, Krivi Put.

49 Nada Prpić Terezina iz Krivoga Puta spomenula je travu po zidovima, misleći najvjerojatnije na ovu biljku. 
Ovaj je kazivač opisao i postupak pri kojem se koristila svićica: E, onda u uho stavi, a na drugoj strani zapali. I da ona ipak nešto djeluje. To je od voska. Mira Tomljanović Ropetina iz Krivoga Puta navela je kako je kod upale uha pomoći mogao jedino liječnik.

Za snižavanje tjelesne temperature bilo je više postupaka. Tako su pojedini kazivači spomenuli upotrebu krumpira koji se izrezan na police stavljao na čelo. ${ }^{50}$ Ivan Pavelić Jandra iz Serdara kazao je: Kako ne bi pomagalo, moralo pomoć. Neki su naglasili kako se krumpir koristio i kod glavobolje. ${ }^{11}$ Pojedini kazivači potvrdili su kako se kod povišene temperature koristila ostika, te su se stavljali oblozi i masirali dlanovi i tabani. ${ }^{52}$ Ivanka Krmpotić Šimunova iz Škobaca, Zdenka Pavelić Vranićeva iz Pavića i Marija Prpić Vinina iz Veljuna kazale su kako se na prsa stavljala domaća mast, a Mira Tomljanović Ropetina iz Krivoga Puta spomenula je obloge od jestivog ulja, napomenuvši da su ljudi u njezino vrijeme imali i penicilin: Taj prašak bi imali za zimu. Zlata Tomljanović Pešina iz Krivoga Puta kazala je kako je ona dvoje svoje djece uljem spasila od visoke temperature: Izlila flašu ulja i zamotala plahtu. I drugu plahtu po njoj suhu i izvuklo ulje sve. Kad je bila malena. Ja san ju sve omotala oko pasa i ručnik, plahtu, ovisi o onome di je višse gorila, sve to ovako iz vlastitog iskustva. (...) Ulje ovo obično. Biljno ulje, kupovno, jestivo ulje. I onda smo mi s tin uljen. Jedanput je evo baš ovoga sina moga. On dobi veliku temperaturu, a nikoga kod kuće s menon, moja se sestra udavala, moja mama ošla i moj muž i još neki susedi otišli, nigdi nikoga, ostali smo ja i Mići sami, ja i mladi sin. Majko moja mila, što ću sada. I ti si bila. Išto ću sada, jadna. Nigdi nikoga, a tablete neman, nišneman. A ja što ću, pa smočin ulje i zamotan i u drugu plahtu zamotan, i ulje izvuklo temperaturu. Marko Tomljanović Rilac iz Katića objasnio je kako se temperatura nastojala sniziti stavljanjem kiselog zelja na dlanove, dok je Ika Pavelić Tomina iz Pavića navela kako se na čelo, ruke i noge stavljalo malo repe, dodajući: A neko ko je moga, taj je odvea i doktoru.

Milan i Zdenka Pavelić Vranićevi iz Pavića spomenuli su da se za glavobolju koristio prašak koji su nazvali kombinirani jer se sastojao od više elemenata: Onda posle su izašli, kako se zva prašak onaj, u prahu što je bija. Kombinirani. On se, kako je kazala Zdenka, nabavljao u 'poteki. To je tako u jednon ko papiriću ovako. To je bilo u prahu. To sad, ja mislin da toga više nema. To je bilo prije. Ova je kazivačica spomenula i da su kod prehlade stavljali noge u vruću vodu i cukar pržili, tako, i mliko livaj. Kad bi ispržili cukar, onda mliko livaj, onda su to kao sirup. Za kašalj i za prehladu.

\section{PRIJELOMI KOSTIJU}

U selu su, prema pričanjima kazivača, postojale osobe koje su znale namjestiti kosti kod prijeloma. ${ }^{53}$ Najčešće su kazivači opisivali kako se namješta noga ovcama. U tom su se slučaju stavile dvije daščice $^{54}$ i privezalo se špagom ${ }^{55}$ ili vunom ${ }^{56}$ te bi nakon određenog vremena ${ }^{57}$ noga zarasla. Mile Prpić Popić

50 O ovom postupku govorili su: Ana i Mile Špalj, Špalji; Josip Prpić Jurina, Mrzli Dol; Draga Tomljanović Rilčeva, Katići; Stjepan Prpić Stipina, Gorica; Ika Pavelić Tomina, Pavići; Ivan Pavelić Jandra, Serdari; Ivanka Krmpotić Šimunova, Škopci; Marija Prpić Vinina, Veljun; Nada Prpić Terezina, Krivi Put; Francika Šojat Babićeva, Šojatski Dolac; Zdenka i Milan Pavelić Vranićevi, Pavići; Zlata Tomljanović Pešina, Krivi Put; Mara Tomljanović Isanova, Krivi Put (kazivačica je jedina spomenula da se u ovu svrhu koristila i izribana jabuka koja se stavljala na tabane i na čelo).

51 Ivan Prpić Kavarica, Lucići (naveo je da se za glavobolju koristila i ostika); Marko Prpić Rus, Rusova Draga; Ivanka Krmpotić Šimunova, Škopci; Zdenka i Milan Pavelić Vranićevi, Pavići; Zlata Tomljanović Pešina, Krivi Put.

52 Ove postupke spomenuli su: Ljubica Prpić, Gorica; Marija Prpić Vinina, Veljun; Zdenka i Milan Pavelić Vranićevi, Pavići (oblozi); Mira Tomljanović Ropetina, Krivi Put; Mirko Prpić Cungo, Krivi Put (masiralo se).

53 O ovoj su temi govorili: Stjepan Prpić Stipina, Gorica; Ljubica Prpić, Gorica; Grgo Prpić Miškec, Gorica; Marija i Ivan Prpić Kavaričini, Lucići; Josip Prpić Jurina, Mrzli Dol; Ika Pavelić Tomina, Pavići (kazala je kako se prijelom kod blaga nije mogao sanirati); Mile Prpić Popić, Popići; Ivan Pavelić Jandra, Serdari; Marija Prpić Vinina, Veljun; Milan i Zdenka Pavelić Vranićevi, Pavići.

54 Ivan Prpić Kavarica, Lucići; Zdenka Pavelić Vranićeva, Pavići. Ljubica Prpić iz Gorice govorila je o četiri daščice.

55 Ljubica Prpić, Gorica; Mile Prpić Popić, Popići.

56 Ivan Prpić Kavarica, Lucići.

57 Ljubica Prpić iz Gorice govorila je o vremenu od osam do deset dana. 
iz Popića dodao je kako se mjesto prijeloma mazalo svinjskom mašću. Marija Prpić Vinina iz Veljuna te Zdenka i Milan Pavelić Vranićevi iz Pavića spomenuli su Migeca iz Veljuna koji je znao namještati kosti i ljudima i blagu.

Što se tiče namještanja kostiju ljudima, dobiveni su različiti odgovori. Tako je Ljubica Prpić iz Gorice navela kako to nije bilo prakticirano u selu budući da je, kako kaže, bolnica naša jako stara u Senju, dok je Stjepan Prpić Stipina dodao: Za naše generacije, mi smo imali tu ambulante, koje su dolazile. Marija Prpić Kavaričina iz Lucića kazala je kako su to znali ljudi u Lici, a na području Krivoga Puta u njihovo je vrijeme bilo doktora, a znalo se ići i u Senj: Isto, isto doktoru su išli. Ako se nešto slomilo, konje i kola metni pa vozi do bolnice, do Senja. Josip Prpić Jurina iz Mrzloga Dola nije se sjetio da je netko znao namještati kosti te je po njegovu mišljenju to znao raditi muškarac u Podgorju, na Vratniku. Ika Pavelić Tomina iz Pavića prisjetila se kako su ljudi koji su to znali raditi k njima dolazili iz pravoslavnog sela Grabove Lokve: Da, ajde po nji, onda oni bi došli, čovik koji je to zna namistit, onda namisti. ${ }^{58}$ Jedino je Mile Prpić Popić iz Popića ispričao kako su ovaj postupak liječenja poznavale starije žene na ovom području: Čovjek kad bi pribija nogu, isto su te stare babe znale namistit odma na svoje misto, namaže isto svinjskom masti dobro i zaveže i dobro krpon $i$ onda isto stavi daske, daske, da to ruka nikud ne ide i onda kad priraste, ostane zdrava. Il noga.

\section{ZUBARI}

$\mathrm{O}$ suseljanima koji su obavljali ulogu zubara zabilježeno je nekoliko priča kazivača. ${ }^{59}$ Stjepan Prpić Stipina iz Gorice kazao je kako je u Krivome Putu zube vadila Maca Pavanova. Milan Prpić Terezin iz Krivoga Puta ispričao je: Bilo je dosta, na primer danas ide zubaru, djeca, ako je zub obolija, odma se liječi. A prije, bilo je to... Mi smo imali susedu, ženska, zapravo ona je naucila od svog oca. I tako, ona je vadila zub, i nema, pola noći, kad god je nekoga zabolija, pokucaj na vrata, i što je - boli zub, sjedi, nema, klista. Josip Prpić Jurina iz Mrzloga Dola i Marko Prpić Rus iz Rusove Drage kazali su kako su njihovi ujaci vadili zube. ${ }^{60}$ Mile Špalj iz Špalja prisjetio se kako su u Plemićima supružnici znali vaditi zube: Evo tu je tamo kuća srušena, ženska i muški, ona je naučila od muža pa je onda i ona vadila. A umrla je to, kad je to bilo, već prije 50 godina A ima tu, živjeli prije 50 godina, da. Marija Prpić Vinina iz Veljuna kazala je kako je njezin otac vadio zube, o čemu su govorili i Milan Krmpotić Zekonja iz Veljuna i Ive Krmpotić Pićica iz Kuljića, dok su Mara i Luka Krmpotić Brndini iz Veljuna potvrdili da je to radio Milan Prpić Markin iz njihova zaselka. Luka je pridodao kako je svako selo imalo zubara, na što je Mara sa smijehom pridodala: Zubara, privatnog. Ivan Prpić Kavarica iz Lucića kazao je kako je otac Milana Blažević Tré́aka iz Mrzloga Dola vadio zube, te je objasnio: Kad te boli, nekud si mora ić. A Senj je daleko. Milan Pavelić Vranić iz Pavića prisjetio se kako je u njegovu zaselku zube vadio Antona Pavelić Sikirica, koji je živio do četrdesetih godina 20. stoljeća, no ispričao je kako je i on jednom prilikom izvadio jednom susjedu zub: U ovoj je kući gori bija je stari pa isto i nevista njegova. Imali su klista prava, tobože, za ono doba, za zube. Čak san i ja jednon coviku tu vadija, isto sotin klištin. Mi se sastali uveče, sidili smo u ovoj gor kući, bili su njih tri i to su oni dva brata i jedan bratić, i ovaj bratić je došo da ga boli zub, da ne može durat da nek jedan izvadi. Nijedan nije tija, da ne more, ne more. Oni pitaju mene da bi li ja, ja san bija mladi, ali sad ima ipak isto već godina. Reko, dajte, ja ću, bija mu je gornji zub, drža mu je jedan glavu zeru glavu gori, ja potega, čas posla. Sa klištin. Klišta su bila prava, originalna. Bilo je tople vode na šparetu koja je kuvala, onda smo zeru držali u toj vodi. Jer dugo klista ta stoje na primer negdje ako nisu zastićena, a ako je kuvala u vodi, ipak je sigurnije malo.

58 Ova je kazivačica navela kako se mjesto prijeloma mazalo mašću ili kremom za ruke.

59 O tome su govorili: Stjepan Prpić Stipina, Gorica; Milan i Nada Prpić Terezini, Krivi Put; Mira Tomljanović Ropetina, Krivi Put; Josip Prpić Jurina, Mrzli Dol; Marko Prpić Rus, Rusova Draga; Mile Špalj, Špalji; Marija Prpić Vinina, Veljun; Luka Krmpotić Brnde, Veljun; Ivan Prpić Kavarica, Lucići; Milan i Zdenka Pavelić Vranićevi, Pavići; Milan Krmpotić Zekonja, Veljun; Ive Krmpotić Pićica, Kuljići.

60 Ujak Marka Prpića Rusa živio je u Pavićima. 
Kazivači su spomenuli kako su se pri vađenju zubiju upotrebljavala kliješta, iako nitko nije znao gdje su se točno nabavljala. ${ }^{61}$ Pojedini su kazivači spomenuli kako se, radi ublažavanja boli, koristila rakija. ${ }^{62}$ Josip Prpić Jurina iz Mrzloga Dola kazao je: Da, obično bi se mećalo malo rakije da rakija malo ublaži tu bol i prvo vadenje i poslije vadenja kad bi se ispiralo to. No, Zdenka i Milan Pavelić Vranićevi iz Pavića objasnili su kako se rakija nije smjela popiti jer, kako kaže Milan: Ne smi rakija se mećat baš odma jer ona otvara krv jošte.

\section{POROD KOD KUĆE 63}

$\mathrm{T}$ ijekom ispitivanja zabilježena je sljedeća priča koja dobro ilustrira u kojim su uvjetima žene prije rađale: Ja kad san došla u bolnicu, kad san došla k doktoru, a već san ja četvero dice rodila i sve imala, a morala san ić na operaciju maternice i sad mene ide mećat na onu kobilu, stol. A neću ja gori. A on gleda-jeste li vi radali? Jesan, moj doktore. A kako ste vi radali? E, kad ću ja van pripovidat kako san ja radala. A nji puno oni mladi ima. Kako smo, ja reko, mi prije radali. Metni baba jedna slame u vriću i to metni tu, ode metni jednu stolicu, ja san se, reko, morala držat za stolicu i klečat na slami i dite kad bi se rodilo, kad bi ispalo u slamu, ako je slame uitilo u šake, to je bilo dobro, koje nije uitilo slame u šake, to je umrlo. Mili moj Bože. Al se on smija. Tako se radalo. Mislin, koja sa sela koja je bila sposobna, pomagale, e. Nije to bilo pomaganja. To je bilo tri dana radanja, dva dana, tri, dok je samo izašlo, jel bilo živo, bilo mrtvo.

Kazivači su naglasili kako su žene na ovom području sve do sredine 20. stoljeća rađale puno djece, kako je, primjerice, kazala Ljubica Prpić iz Gorice: tu su žene sve po deset, dvanaestero, trinaestero. No, ista je kazivačica pridodala kako se često događalo da su djeca umirala, nije bilo kuće di nije dite umrlo. Zlata Tomljanović Pešina iz Krivoga Puta posvjedočila je kako je njezinoj baki od bolesti zvane španjolica ${ }^{64}$ umrlo petero djece.

Po riječima kazivača, može se zaključiti da su žene negdje do šezdesetih godina 20. stoljeća još rađale kod kuće. ${ }^{65}$ Pojedine su kazivačice navele kako žene zbog srama nisu odlazile ginekolozima, te i u tome vide jedan od mogućih razloga poroda kod kuće. Stjepan Prpić Stipina iz Gorice kazao je kako su žene njegove generacije, dakle one rođene sredinom 20. stoljeća, rađale u bolnici, a sam ih je često tamo vozio: Posle san ja ovaj bio tu kao Crveni križ, ja san ima kombija, 40 godina, 35, onda po mene su išli svi koje su radale, ove mlade. Jedna mi je rodila tu doli, Mara ova Draganova. Tu je rodila dol na cesti, nismo išli u bolnicu dalje, nego natrag vratili. Mara i Luka Krmpotić Brndini iz Veljuna objasnili su kako je porod u bolnici bio sigurniji zbog bolje opremljenosti i stručnosti, posebice ako bi došlo do težeg poroda. Žene su odlazile u bolnicu u Senj i Rijeku. Ana Špalj Cucina iz Krivoga Puta rekla je kako odlazak u bolnicu nije

61 Nada i Milan Prpić Terezini, Krivi Put; Josip Prpić Jurina, Mrzli Dol; Tome Špalj, Špalji; Marija Prpić Vinina, Veljun; Luka i Mara Krmpotić Brndini, Veljun; Milan i Zdenka Pavelić Vranićevi, Pavići.

62 Stjepan Prpić Stipina, Gorica; Nada Prpić Terezina, Krivi Put; Josip Prpić Jurina, Mrzli Dol; Mara i Luka Krmpotić Brndini, Veljun.

63 O ovoj su temi govorili: Ljubica Prpić, Gorica; Stjepan Prpić Stipina, Gorica; Milan i Nada Prpić Terezini, Krivi Put; Mira Tomljanović Ropetina, Krivi Put; Mirko Prpić Cungo, Krivi Put; Marija i Ivan Prpić Kavaričini, Lucići; Josip i Milka Prpić Jurini, Mrzli Dol; Ika Pavelić Tomina, Pavići; Marko Prpić Rus, Rusova Draga; Francika Šojat Babićeva, Šojatski Dolac; Ana Špalj, Špalji; Marija Prpić Vinina, Veljun; Nevenka Krmpotić Aneličina, Veljun; Mara i Luka Krmpotić Brndini, Veljun; Eleonora Prpić Lejina, Veljun; Jadranka Tomljanović, Veljun; Zdenka Pavelić Vranićeva, Pavići; Milan Krmpotić Zekonja, Veljun; Ive Krmpotić Pićica, Kuljići; Ana Šojat Colaševa, Francikovac; Tome i Ana Špalj Cucini, Krivi Put; Branko Tomljanović Ropeta, Krivi Put.

64 Kazivačica je objasnila da je to vrsta tuberkuloze.

65 Mirko Prpić Cungo iz Krivoga Puta, Eleonora Prpić Lejina iz Veljuna i Branko Tomljanović Ropeta iz Krivoga Puta kazali su da su žene kod kuće rađale do šezdesetih godina. Josip Prpić Jurina kazao je da se to počelo mijenjati nakon Drugoga svjetskog rata. Isto je mišljenje iznio i Luka Krmpotić Brnde iz Veljuna. Tome Špalj Cucin iz Krivoga Puta kazao je da su žene rađale kod kuće do prije trideset godina. 
bio ustaljen: Dospela bi ona da je to bilo običaj. One nisu na to davale kad će se rodit, sad tih priprema, ništa, to je sve bilo onako kako bude.

Kazivači su naglašavali da je trudna žena, trudnica, noseća žena ${ }^{66}$ morala sudjelovati u svim kućanskim i gospodarskim poslovima.

Pri porodu su ženama pomagale babice, ${ }^{67}$ primalje koje su, kako su objasnili kazivači, zahvaljujući iskustvu znale što treba činiti. Tako je Nada Prpić Terezina iz Krivoga Puta kazala: Žene koje su više radale, te su onda drugoj primale i tako, dok je Josip Prpić Jurina iz Mrzloga Dola pojasnio: Bila je priučena utoliko ukolko je više poroda obavila. To je bila praksa i kvalifikacija. Mirko Prpić Cungo rekao je da je Marija Prpić, koja je živjela do sredine 20. stoljeća, bila prva učena babica na Krivom Putu. Milan Prpić Terezin o ženama koje su pomagale pri porodu ispričao je: Pa sad ode mi smo imali baš babicu, učena babica. A bilo je i ovih nadribabica. Stručnost možda jednako ova koja nije završila i ova. A prije su žene lakše radale jer su puno radile, nisu nosile ko danas. Tako da ona je mogla celi dan kopat i doć u kuću, pa ima neke su iz Senja išle pa ga donile, samo je rodila i donila. Kazivačeva supruga Nada pridodaje: Ovoj di se smatralo da će bit teži porod, onda su ovu tobož učenu. Jer učenu je trebalo platit. Pojedini su se kazivači prisjetili kako su neke žene rodile same, bez ičije pomoći, ${ }^{68}$ a zabilježeno je i sjećanje na ženu iz Burića koja je rodila vraćajući se iz Senja kući: ${ }^{69}$ Jedna žena išla iz Senja pješice, to ujutro sa magaretom gonila stvari prodati, i kupila što je trebalo, sapuna i ono što je mogla. I uhvatija ju je porod na planinan gori. I rodila i što je imala rubac na glavi salvet. Salvet su to ti je jedna krpa kao kuhinjska, 4 coška i to su zvali salvet. I ona je rodila curicu i zamotala je u to i donila do prve kuće di je naišla, trebalo je doć i dignit se, moš mislit.

Odgovori se kazivača razlikuju kad je u pitanju položaj u kojem su žene rađale. ${ }^{70}$ Nevenka Krmpotić Aneličina i Mara Krmpotić Brndina iz Veljuna kazale su kako su rađale ležeći, dok je nekoliko kazivačica navelo da su klečale. ${ }^{71}$ Marija Prpić Vinina iz Veljuna ispričala je: Ovako lipo kleknit ko da ispovijeda, kleknit i ovako se na što nagni i na to se radaj. Metni robu, metni. Kazivačica je objasnila da su žene u tom položaju možda imale više snage.

Zabilježene su i dvije priče o tome kako je ženama kod poroda pomagala boca u koju su puhale: ${ }^{72} \mathrm{Kad}$ se poradala, on i ja smo bili ovako dica, jedno 10 godina, tu je susjeda radala, a mi škiljali kroz prozor. A ona je legla na pod $i$ stavila se boca jedna, flaśa i ona je puhala u to $i$ to je onda, šta ja znan, prije ispalo.

Pojedini su kazivači spomenuli vjerovanje o djeci koja su rođena u posteljici. ${ }^{73}$ Milka Prpić Markina iz Veljuna kazala je: To su zvale babe u košuljici. Veli, ti si se rodija u košuljici pa si sretan. Tome Špalj Cucin iz Krivoga Puta objašnjava: Kaže, rodija se u posteljici, u košuljici. To kad je nekon dobro u životu, pa onda reče rodio se u košuljici. Rodio se u košuljici, to kad mu je nešto ugodno u životu.

Kazivači su potvrdili kako muškarci obično nisu bili prisutni kod poroda. ${ }^{74}$

66 Mara i Luka Krmpotić Brndini iz Veljuna. U Upitnici Etnološkog atlasa Jugoslavije zabilježeno je: $z a$ ženu u porođaju se kaže da je u drugom stanju (UEA, IV, 124, Fd 241/478).

67 Izraz su upotrijebili: Milan Prpić Terezin, Krivi Put; Mirko Prpić Cungo, Krivi Put; Francika Šojat Babićeva, Šojatski Dolac; Marija Prpić Vinina, Veljun; Mara i Luka Krmpotić Brndini, Veljun; Ive Krmpotić Pićica, Kuljići; Tome Špalj Cucin, Krivi Put. Marija Prpić Vinina ih je još nazvala: žene koje su babile.

68 O tome su govorile Ljubica Prpić iz Gorice i Milka Prpić Jurina iz Mrzlog Dola navodeći primjere svojih susjeda.

69 Sjećanje Mare Krmpotić Brndine i Eleonore Prpić Lejine iz Veljuna.

70 U Upitnici Etnološkog atlasa Jugoslavije zabilježeno je da žena rada ležeći ili klečeći u postelji (UEA, IV, 124, Fd 241/478).

71 Marija Prpić Vinina, Veljun; Mara Krmpotić Brndina, Veljun; Eleonora Prpić Lejina, Veljun.

72 Stjepan Prpić Stipina, Gorica; Jadranka Tomljanović, Veljun.

73 O vjerovanjima da je dijete rođeno u posteljici sretno govorili su: Milka Prpić Markina, Veljun; Tome Špalj Cucin, Krivi Put; Zlata Tomljanović Pešina, Krivi Put.

74 Ivan Prpić Kavarica, Lucići; Ana Špalj, Špalji; Nevenka Krmpotić Aneličina, Veljun; Zdenka Pavelić Vranićeva, Pavići; Luka i Mara Krmpotić Brndini, Veljun. Ivan Prpić Kavarica kazao je kako boduli imaju običaj reći da su rodili, obadvoje, $i$ ona $i$ on te da zajedno idu leći. 
Posjet novorođenom djetetu i njegovoj majci pojedini su kazivači nazvali babinje. ${ }^{75}$ Eleonora Prpić Lejina iz Veljuna ispričala je: Kad bi se beba rodila, onda žene, malo je koja radala u bolnici, to se radalo doma, onda bi se uradilo, onda bi metnilo ženu malo leć, nije se to ležalo puno, malo je to bilo ležanja. Obavezno bi se kokoš klala kad bi žena rodila, tobož kao kokošja juha je najbolja da se žena oporavi, da joj mlijeko dođe i to, to je svaka. Onda su dolazili, babinje kad bi bile. A posle jedno osam dana, već kako bi. Ko je koga ima doć, onda obavezno bi žene nosile, ko je ima kokoš, i to živu, ne mrtvu, živu kokošbi morali donijet, mislim morali, ko je iša, jel. I onda se nosila boca crnog vina i za bebu po mogućnosti ko je što ima, ko nije, e donesi malo kave, šéera, to je bilo delikates. E, kad je došlo bebi, beba je ležala, ko je ima kolijevku, ko na krevetu, ovisi kako je ko, i bila je pokrita odozga krpon po glavi. I sad kad bi došlo, nije se smilo valjda na bebu doć, morašsi posjedit malo, i sad kad bi iso gledat, prije si mora pogledat u svoje nokte da ne bi bebu ureka. Prije u nokte svoje, onda u bebu onako veselo. Toliko to znan. Onda bi otkrili bebu, da se vidi, ako je ko bio u mogućnosti, daj joj koji dinar ili ovako što metni joj da bebi za sapun, ko nije, nije. Josip Prpić Jurina iz Mrzloga Dola kazao je da se u posjet odlazilo nakon osam dana i obično nosilo kokoš, s tim da su i on i njegova supruga Milka naglasili kako su to činile samo žene. Marija Prpić Vinina iz Veljuna kazala je kako se obično donosilo vino i kokoš ${ }^{76}$ te da se za taj posjet reklo donila mi babine. Kazivačica je spomenula kako se u posjet dolazilo treći ili četvrti dan nakon poroda. Zdenka Pavelić Vranićeva iz Pavića kazala je kako bi se obično dolazilo nakon pet ili šest dana ili nedjeljom, kada bi bilo više slobodnog vremena, potvrdivši da su u posjet išle samo žene. Ive Krmpotić Pićica iz Kuljića kazao je kako se posjećivalo već dan nakon poroda i obično se nosila kokoš, dok je Milan Krmpotić Zekonja iz Veljuna pridodao da bi se darivalo i kavu, piće, šećer, naglašavajući kako to nije bilo ka danas.

Nekoliko je kazivačica potvrdilo da su žene prije dojile dulje nego danas, ${ }^{77}$ do dvije, ${ }^{78}$ pa čak i tri godine. ${ }^{79}$ Jedna od kazivačica je pojasnila: A jesu dojile dulje nego sada, sad neće nijedna da doji. (...) A po dvi godine. Onda znate kako. Danas ima sredstava svakakvih $i$ sve, a žene su van prije radile ovako - na dvi godine je dojila dite i nije imala menzis. I onda do dvi godine bi dojila, poslije kad prestala dojit, onda zanesi opet drugo.

\section{HIGIJENA}

$K^{2}$ ao glavni higijenski problem na ovom području kazivači su istaknuli nestašicu vode. Tako su Nada Prpić Terezina i Mira Tomljanović Ropetina iz Krivoga Puta kazale da se po vodu ponekad, kad je bila velika suša, odlazilo u Brinje. ${ }^{80}$ Josip Prpić Jurina iz Mrzlog Dola prisjetio se: A loše, loše. Za vodu je bilo jako loše. Tu su ljudi bili očajni, nisu imali šterni, ti cisterni, onda kad bi susjedi došli pri kraju, onda ne bi bilo, muku muči. (...) Bila je jako loša higijena. Milan Prpić Terezin iz Krivoga Puta objasnio je: Ma kakva kupaona. WC. Evo ovde što smo mi imali, nije to baš bio pravi, a ipak pod krovon WC, a ostalo poljsko je to

75 Milka Prpić Jurina, Mrzli Dol; Eleonora Prpić Lejina, Veljun; Zdenka Pavelić Vranićeva, Pavićí; Ana Špalj Cucina, Krivi Put. Marija Prpić Vinina iz Veljuna kazala je da bi se reklo: Donila mi je babine. Ive Krmpotić Pićica iz Kuljića naveo je naziv babine. U Upitnici Etnološkog atlasa Jugoslavije zabilježen je naziv babine (UEA, IV, 124, Fd 241, 478).

76 Crno vino spomenuo je i Tome Špalj Cucin iz Krivoga Puta, dok je njegova supruga Ana kazala da se donosila kokoš.

77 O tome su govorile: Milka Prpić Markina, Veljun; Ana Špalj Cucina, Krivi Put; Zlata Tomljanović Pešina, Krivi Put; Nada Prpić Terezina, Krivi Put; Marija Prpić Vinina, Veljun. U Upitnici Etnološkog atlasa Jugoslavije zabilježeno je: Mater doji dijete do 1 god. Ako imade mlijeka onda to radi i duže (UEA, IV, 124, Fd 241, 478).

78 Nada Prpić Terezina, Krivi Put; Milka Prpić Markina, Veljun. Marija Prpić Vinina iz Veljuna kazala je: $i$ do tri godine.

79 Marija Prpić Vinina iz Veljuna i Ana Špalj Cucina iz Krivoga Puta koja je kazala: malo manje od četiri godine.

80 Detaljnije o opskrbi vodom na području Krivoga Puta može se pročitati u radu Opskrba vodom Danijele Birt i Matije Dronjića u prvom svesku Monografije. 
bilo, dok je njegova supruga Nada pridodala kako kupaone niko nije ima, te se pranje obavljalo pomoću lavora i drvenih banji i kaci.

Pojedini su kazivači govorili o upotrebi sapuna ${ }^{81}$ naglašavajući kako su ga izrađivali kod kuće, iako se mogao kupiti i u trgovinama. Tako je, primjerice, Mira Tomljanović Ropetina objasnila kako se sapun pravio od ovčjih ili goveđih kostiju i sode. Mara Krmpotić Brndina iz Veljuna kazala je: Kosti i ono, e, loj, sve se kuhalo. Onda se to znalo, kako to zaledi. Onda se sledi i onda se reže. Metneš na hladno. Josip Prpić Jurina iz Mrzloga Dola objasnio je kako su sapun izrađivali samo pojedinci te bi se od njih onda kupovao i to: Obično u naturi se to davalo. (...) A daj ili krumpira malo ili bilo što, trampa je bila.

Za pranje zubiju upotrebljavao se ugljen. ${ }^{82}$ Milan Prpić Terezin iz Krivoga Puta usporedio je to s današnjicom: Danas, kad vidiš, imaš kaladont i četkicu za zube prat, prije onoga ugljena, mlade cure $i$ dečki, onda metni prston, zubi bili bijeli. Nije iša zubaru, niti je blombira ni vadija. A danas ka dete od osnovne škole popravlja zube.

Rublje se pralo pomoću lukšije, luga. ${ }^{83}$ Marija Prpić Kavaričina iz Krivog Puta ovako je opisala postupak: To je bija ovaj lug, iz špareta. U tom smo lugu kuvali veš i prali. Bile su, bile, posebne drvene kace. Po tri dana peri veš. Prvi dan ga treba metnit u u drvenu kacu, ${ }^{84}$ doli je imala čep. (...) I lug taj i cidit $i$ kuvat jedno 2, 3 puta, po 5 puta kuvat tu vodu. I doli je istakat i opet nazad mećat kuvat. I to je morala noćit u tom. I sutradan peri, isperi, se bililo. (...) Kuvalo se na šparetu, pa se kacu drvenu livalo, a doli je na onaj čep išla voda. Samo se kuvalo i livalo 2, 3 puta u tu vodu i to je moralo prinoćit u toj vodi $i$ sutradan se pralo. Onda sutradan isperi i peri u mlakoj $i$ u ledenoj i tako. To je bila mašina $i$ to je bilo sve. ${ }^{85}$ Mira Tomljanović Ropetina iz Krivoga Puta i Zdenka Pavelić Vranićeva iz Pavića pridodale su kako se lug lijevao u kacu kroz tkaninu koja se nazivala lužnjak, dok je Ivan Prpić Kavarica iz Lucića objasnio kako se rublju dodavalo još modrilo koje je davalo, kako kaže, tu jednu nijansu vešu. Pri pranju se upotrebljavala i prakljača ${ }^{86}$ drvena daska kojom se udaralo po rublju. Marija Prpić Kavaričina u šali je kazala: I tuci. Moralo blato ić van kad je dobilo batina.

Mira Tomljanović Ropetina iz Krivoga Puta objasnila je da se lug koristio sve dok prašci za rublje nisu postali dostupniji: Kako su praški dolazili, tako se to puštalo - taj lug. Ivan Prpić Kavarica iz Lucića kazao je da je to bilo sredinom 20. stoljeća.

Ivan Prpić Kavarica pridodao je kako su se muške košulje često štirkale štirkon koja se, prema riječima njegove supruge Marije, nabavljala u trgovinama. Ondje se kupovala i pegla: A pegla je bila, vaik je bilo pegle na ugljen. Metni u peglu žerave i peglaj. ${ }^{87}$

81 Mira Tomljanović Ropetina, Krivi Put; Marija Prpić Kavaričina, Lucići; Josip Prpić Jurina, Mrzli Dol; Marko Prpić Rus, Rusova Draga; Nevenka Krmpotić Aneličina, Veljun; Eleonora Prpić Lejina, Veljun; Zdenka Pavelić Vranićeva, Pavići. Marija Prpić Kavaričina iz Lucića naglasila je kako se domaćim sapunom mazalo za zaštitu od uboda komaraca i mušica.

82 Milan Prpić Terezin, Krivi Put; Marija Prpić Vinina, Veljun; Luka Krmpotić Brnde, Veljun; Eleonora Prpić Lejina, Veljun.

83 Josip Prpić Jurina, Mrzli Dol; Nada i Milan Prpić Terezini, Krivi Put; Mira Tomljanović Ropetina, Krivi Put; Marija i Ivan Prpić Kavaričini, Lucići; Ika Pavelić Tomina, Pavići; Marko Prpić Rus, Rusova Draga; Marija Prpić Vinina, Veljun; Luka Krmpotić Brnde, Veljun; Zdenka Pavelić Vranićeva, Pavići; Eleonora Prpić Lejina, Veljun.

84 Ivan Prpić Kavarica kazao je da su se kace nabavljale ili na sajmovima u Brinju i Otočcu ili su ih Kutarevci, koji su bili poznati po njihovoj izradi, prodavali po selima. Detaljnije vidi u radu Tihane Rubić Tradicijska trgovina i sajmovi u prvom svesku Monografije.

85 Josip Prpić Jurina iz Mrzlog Dola jedini je kazao kako se dodavala neka trava koja bi ublažila miris lukšije, no nije se mogao sjetiti njezina imena.

86 To su spomenuli Marija i Ivan Prpić Kavaričini iz Lucića i Milan Prpić Terezin iz Krivoga Puta.

87 Riječi Marije Prpić Kavaričine iz Lucića. 


\section{ODNOS SLUŽBENE I NARODNE MEDICINE}

工 $\mathrm{z}$ brojnih zapisa o načinima liječenja može se zaključiti kako je narodna medicina bila važan dio života Krivopućana. Razlike koje postoje u načinima liječenja i u različitoj zastupljenosti odgovora o poznavanju pojedinoga postupka ili ljekovite biljke, govore kako su postojali različiti načini pomaganja kod bolesti ili različitih povreda, kako kod ljudi, tako i kod stoke. Kao potvrdu tome Zdenka Pavelić Vranićeva iz Pavića, vezano uz načine snižavanja povišene tjelesne temperature, kazala je: Jesu, mećali su i krumpir $i$ ostiku na dlanove i na prsi i mast svinjsku $i$ tako je to, kako koja baba je ličila. O velikom znanju ponajprije žena, koje su one stekle prvenstveno zahvaljujući iskustvu, sažeto je kazala Mara Krmpotić Brndina iz Veljuna: Sve su to prvo žene još bolje znale. Naravno, gledajući razlike u pojedinim postupcima liječenja i navedenim različitim ljekovitim svojstvima pojedinih biljaka, u obzir treba uzeti i sjećanje kazivača koje ponekad igra ključnu ulogu u istraživanju. Tako je, primjerice, zbog velikog broja ljekovitog bilja koje su stanovnici ovoga kraja poznavali, moguće da tijekom razgovora neke nisu ni spomenuli.

Tijekom istraživanja zabilježeno je nekoliko primjera korištenja naslijeđenog znanja danas. Tako Zlata Tomljanović Pešina iz Krivoga Puta, koja danas živi u Senju, bere čajeve na Krivome Putu (sl. 16). Iako posjeduje i knjigu iz koje je naučila pojedinosti o ljekovitom djelovanju biljaka, naglasila je: $A$ ja iman to nasljedstvo od moje bake. Da. Ona je, nije imala nikakvih knjiga, nego iz vlastitog iskustva, ona je to brala. (...) Ko van je iša doktoru. Sa travama se liječilo. I one su iz vlastitog iskustva to primjenjivale. Tako da smo, velin van, iz ranijeg doba $i$ tako. Meni to leži $i$ ja to volin. I velin van, jučer se nas petero spremilo da idemo brati, ustavi nas kiša. Moja nećakinja, njezin muž, moja sestrična, nas dve, spremili se da idemo u Krivi Put, idemo brat trave, idemo čaj brat, medutin kiša, tako da nismo otišli nikuda. A ja to volin. Iman i nećakinju, ona voli te trave, ona isto voli ić po šumi i brat. A ja uživan po šumi. Njezina kći Višnja ispričala je kako joj je jednom prilikom iz Zagreba donijela čajeve, no Zlati se oni nisu toliko svidjeli, smatrala je da su kao prašina.

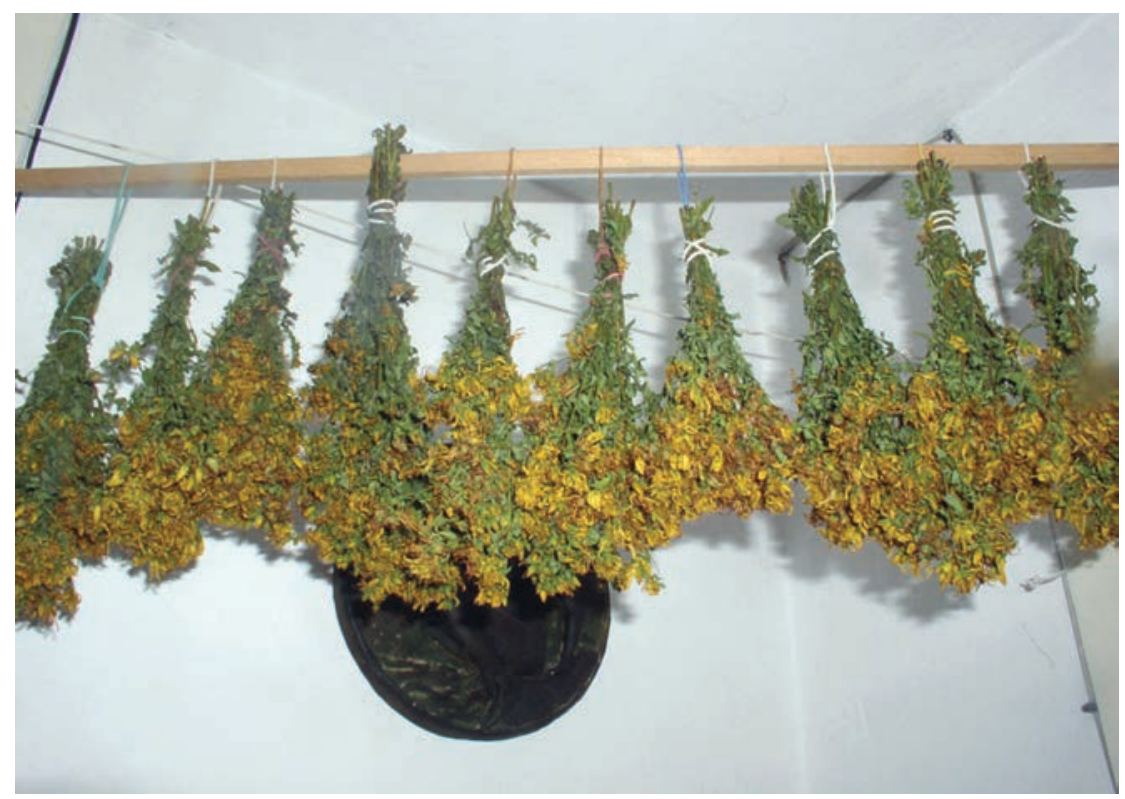

Slika 16: Gospina trava snimljena u kucic Zlate Tomljanović Pešine u Senju; snimila Petra Kelemen, sppanj 2005.

Slično je ispričala i Milka Prpić Markina iz Veljuna: Ima raznih čajeva, samo što mi ne običavamo. A to je sve dobro. Mi mislimo samo da u apoteki, a to ima svagde. Ovoga i doma ima, još boljega nego u apoteki. (...) A mi samo znamo kupovat one, a ovo sve domaće propustamo, ovo bi sve trebalo lipo domaće ubrat. (...) A sve ima ovo čajeva, mi ne umijemo. Mi sve u apoteki, ono farba. Šipkov čaj kad se nabere i kad ga ima domaćega, ovo iz apoteke - to je ko farba. Ne valja. 
Ive Krmpotić Pićica iz Kuljića kazao je kako on i supruga nikada nisu kupovali čajeve. Također imaju knjigu o ljekovitom bilju, ali je kazivač naglasio: to san ja primija od roditelja. Ana Šojat Colaševa iz Francikovca, koja sa svojim domaćim proizvodima, među ostalim i raznim čajevima i mastima, sudjeluje na izložbi Jesen u Lici, kazala je kako je o travama naučila i od starijih žena i iz članaka objavljenih u Gospodarskom listu (sl. 17). Navela je kako starije žene znaju dosta toga o ljekovitim travama, no mlađe se ne bave puno time. ${ }^{88}$

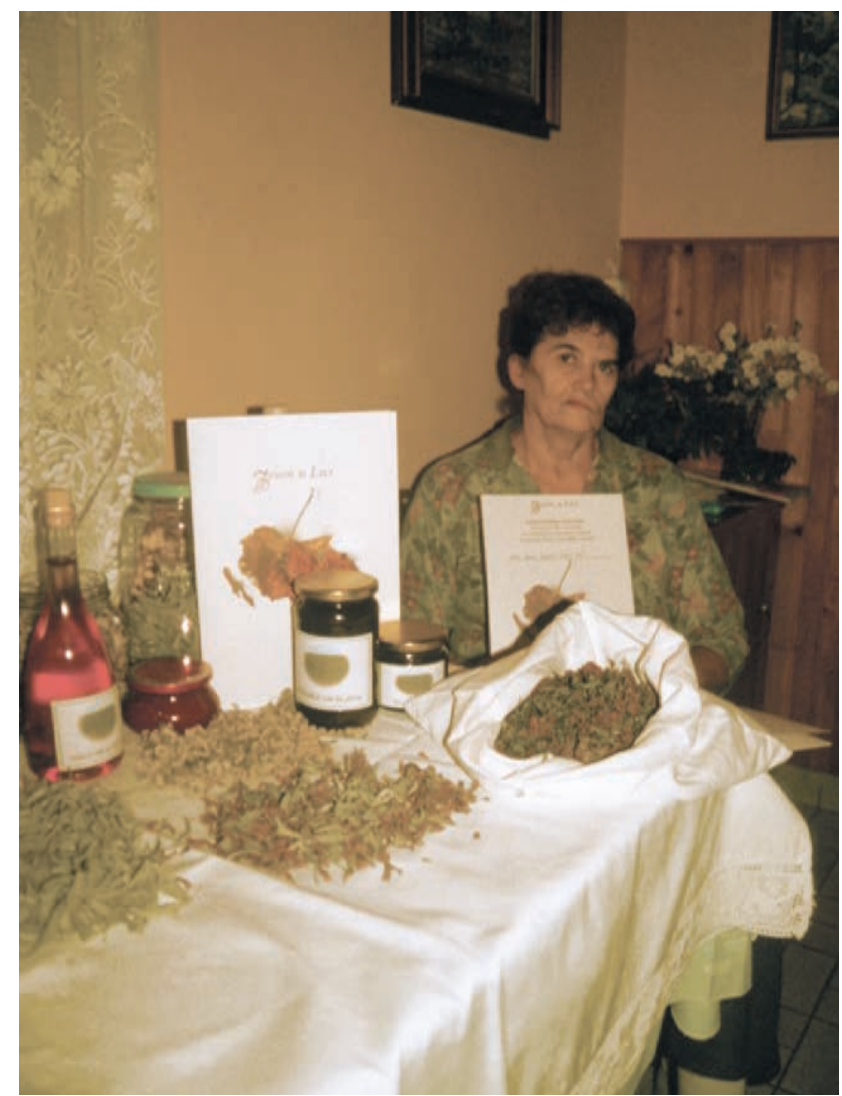

Slika 17: Ana Šojat Colaševa iz. Francikovca s vlastitim domaćim proizvodima od rąličitih biljaka; snimio Augustin Peric, studeni 2007.

Branko Tomljanović Ropeta i Zlata Tomljanović Pešina iz Krivoga Puta prisjećaju se kako je šezdesetih i sedamdesetih godina u Krivome Putu zadruga otkupljivala, između ostalog, i ljekovito bilje. Zlata Tomljanović naglasila je bogatstvo ovog kraja različitim biljem i šumskim plodovima koje, po njezinu mišljenju, nažalost, ostaje neiskorišteno.

Zabilježena su i kazivanja o veterinarima na ovom području. ${ }^{89}$ On je prema riječima kazivača uvijek dolazio iz Senja, a u samom Krivome Putu nikada nije imao svoju ambulantu. Branko Tomljanović Ropeta iz Krivoga Puta objasnio je: Veterinar bio isto u Senju. Uvijek bio u Senju. Jer teško bilo pokriti iz Krivog Puta Vratnik i Krasno, bilo mu najzgodnije u Senju, more pokrivat sva ova gravitirajuća područja. Mile Prpić Popić iz Popića objasnio je kako su ljudi imali povjerenja u veterinara riječima: Po veterinara su radije išli. Da će

88 U studenom 2007. godine obavljena su dodatna snimanja i kraća dopunska ispitivanja te smo tom prigodom ponovno posjetili Anu Šojat Colaševu. Saznali smo da je na manifestaciji Jesen u Lici te godine osvojila treću nagradu za svoje proizvode.

89 O tome su govorili: Milan Krmpotić Zekonja, Veljun; Ive Krmpotić Pićica, Kuljići; Mara i Luka Krmpotić Brndini, Veljun; Mile Prpić Popić, Popići; Milan Prpić Markin, Veljun; Zlata Tomljanović Pešina, Krivi Put; Branko Tomljanović Ropeta, Krivi Put. 
on to bolje naredit i sve. Uz njega su ljudi i sami znali pomoći blagu kuhajući čajeve ili pozivajući pojedince koji su znali postupke liječenja koji nisu bili poznati svima, primjerice kod ujeda zmije. Milan Krmpotić Markin iz Veljuna napomenuo je kako je ponekad dolazilo i do sljedeće situacije: Što ostalo živo, ostalo, što krepalo, krepalo. Zlata Tomljanović Pešina iz Krivoga Puta prisjetila se događaja iz svog djetinjstva kada je jedan suseljanin snalažljivo spasio njihovu kravu budući da veterinar nije bio u blizini: A ja se sjećan kad bi se krava rosne djeteline, jedanput jedna krava se naša najela i došla je kući i napila se vode, kad se napila vode, ona je buknula, ona je htjela puknut, ajme meni, jadna ti san ja. Nedilja je bila, curica bila, desetak godina. I jedan rođak naš, oni nisu znali kako će se snać, što će napravit, hoće li veterinara dočekat ili iz Brinja ili iz Senja, dok on dode, nije to bilo auto ko danas pa brzo će to doć, to je fijakeron se vozilo. I on dode i uzme ovoliki nožić i ona se ispuha, ono splasni, ono se zatvorilo, uopće nije se trebalo ni šivat ni niš, mali je nožić bija, to se zatvorilo, zaraslo i ništa nije bilo i ostala živa.

U sjećanju je kazivača i ambulanta u Krivome Putu, ${ }^{90}$ koja je prema njihovim riječima radila šezdesetih godina 20. stoljeća. ${ }^{91}$ Dok nje nije bilo, odlazilo se u bolnicu u Senj ili Rijeku. ${ }^{92}$ Zlata Tomljanović Pešina iz Krivoga Puta o odlasku liječniku kazala je: Ako je bilo baš hitno za doktora. (...) A recimo što nije bilo hitno za doktora, i da se zbilja baš moralo otić, onda su išli. Ove sitnije - to se liječilo sami. Ova je kazivačica ispričala kako su i sami liječnici koristili načine liječenja koje poznaje narodna medicina: doktor sebi stavlja krumpir na čelo, a ljudima daje recepte, objašnjavajući ovo davanje prednosti, kako je kazala, prirodnom načinu liječenja, time što svaka tableta jedno liječi, a drugo truje.

Tijekom istraživanja narodne medicine na ovome području, dobiveni su brojni podaci o načinima liječenja. Poznavanje ljekovitih trava i postupaka koje su ljudi prakticirali u slučajevima bolesti, kao i

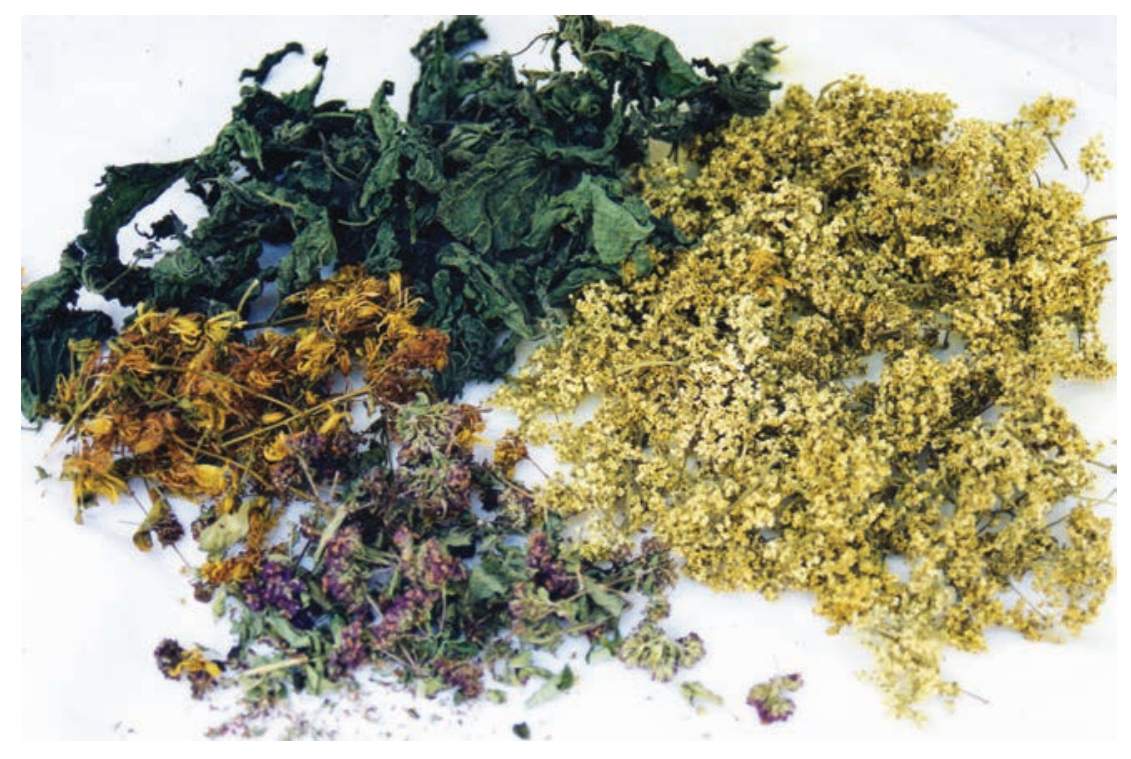

Slika 18: Bagga, metvica, kopriva i gospina trava snimljene u kući Drage i Marka Tomljanovića Rilčevih; snimio Augustin Perić, lipanj 2003.

90 O tome su govorili: Milan Krmpotić Zekonja, Veljun; Ive Krmpotić Pićica, Kuljići; Luka Krmpotić Brnde, Veljun; Milka i Milan Prpić Markinovi, Veljun; Zlata Tomljanović Pešina, Krivi Put; Branko Tomljanović Ropeta, Krivi Put; Tome Špalj Cucin, Krivi Put.

91 Branko Tomljanović Ropeta iz Krivoga Puta kazao je da je radila od pedesetih do sedamdesetih godina 20. stoljeća, Milan Krmpotić Zekonja iz Veljuna naveo je da je radila šezdesetih, a Tome Špalj Cucin iz Krivoga Puta od 1961. do 1966. ili 1967. godine.

92 Senj su spomenuli svi kazivači koji su govorili o ovoj temi, a Rijeku je spomenuo Branko Tomljanović Ropeta iz Krivoga Puta. Već je u ulomku o porodu kod kuće rečeno da su žene odlazile rađati u riječku bolnicu. 
odnosi poštovanja prema osobama koje su poznavale pojedine načine liječenja, govore da je narodna medicina bila važan segment života stanovnika ovog kraja. Neki elementi narodne medicine žive i danas i uspješno su uklopljeni u vrijeme u kojem je službena medicina pristupačnija nego što je bila u vremenu do sedamdesetih godina 20. stoljeća, a na koje se odnosi i većina podataka prikupljenih terenskim istraživanjem (sl. 18).

Naime, usred iseljavanja stanovništva, ali i bolje povezanosti s ostalim krajevima te lakšeg dolaska do potrebnih lijekova i liječnika, narodna medicina gubi primat koji je do tada imala. No, pozitivni primjeri upotrebe ljekovitog bilja pokazuju mogućnosti uključivanja elemenata narodne medicine u suvremeni život, kako kroz praktičnu primjenu, tako i kroz stvaranje prepoznatljivih proizvoda i suvenira te njihovo uključivanje u turističku ponudu ovoga područja.

\section{LITERATURA I IZVORI:}

BRENKO, Aida, Željko DUGAC, Mirjana RANDIĆ (2001): Narodna medicina. Etnografski muzej Zagreb, Zagreb.

Upitnice Etnološkog atlasa (UEA), svezak III., tema broj 87. Umivanje, kupanje, pranje; svezak IV. (Fd241/651, Fd 241/478), tema broj 124. Porod, dojenje, prvi zub; Arhiv Odsjeka za etnologiju i kulturnu antropologiju, Filozofski fakultet u Zagrebu. 